\title{
Deffinition of the existing cooling reference systems
}

IEA SHC TASK 53 | New generation solar cooling \& heating systems (PV or thermally driven) 

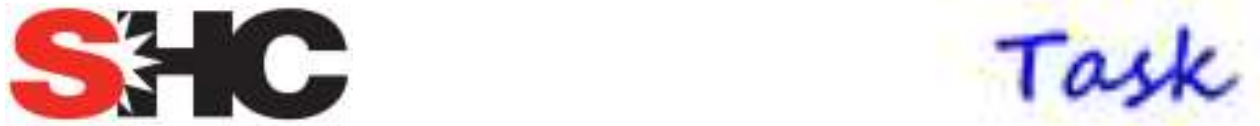

SOLAR MEATING \& COOLNG PROGRAMME

INTERNATIONAL. ENERGY AGENCY

\section{Definition of the \\ existing cooling reference systems}

\section{IEA SHC Task 53 - Activity A1}

Tim Selke, AIT Austrian Institute of Technology GmbH/ Center for Energy, Giefinggasse 2, 1210 Vienna, Austria, +43 (0) 664825 1008, tim.selke@ait.ac.atDate

SHC Task 53/Report A1, DOI: 10.18777/ieashc-task53-2019-0001

The contents of this report do not necessarily reflect the viewpoints or policies of the International Energy Agency (IEA) or its member countries, the IEA Solar Heating and Cooling Technology Collaboration Programme (SHC TCP) members or the participating researchers. 
The Solar Heating and Cooling Technology Collaboration Programme was founded in 1977 as one of the first multilateral technology initiatives ("Implementing Agreements") of the International Energy Agency. Its mission is "to enhance collective knowledge and application of solar heating and cooling through international collaboration to reach the goal set in the vision of solar thermal energy meeting $50 \%$ of low temperature heating and cooling demand by 2050.

The members of the IEA SHC collaborate on projects (referred to as "Tasks") in the field of research, development, demonstration (RD\&D), and test methods for solar thermal energy and solar buildings.

Research topics and the associated Tasks in parenthesis include:

- Solar Space Heating and Water Heating (Tasks 14, 19, 26, 44, 54)

- Solar Cooling (Tasks 25, 38, 48, 53)

- Solar Heat for Industrial or Agricultural Processes (Tasks 29, 33, 49, 62)

- Solar District Heating (Tasks 7, 45, 55)

- Solar Buildings/Architecture/Urban Planning (Tasks 8, 11, 12, 13, 20, 22, 23, 28, 37, 40, 41, 47, 51, 52, 56, 59)

- Solar Thermal \& PV (Tasks 16, 35, 60)

- Daylighting/Lighting (Tasks 21, 31, 50,61)

- Materials/Components for Solar Heating and Cooling (Tasks 2, 3, 6, 10, 18, 27, 39)

- Standards, Certification, and Test Methods (Tasks 14, 24, 34, 43, 57)

- Resource Assessment (Tasks 1, 4, 5, 9, 17, 36, 46)

- Storage of Solar Heat (Tasks 7, 32, 42, 58)

In addition to our Task work, other activities of the IEA SHC include our:

$>$ International Conference on Solar Heating and Cooling for Buildings and Industry

$>$ Solar Heat Worldwide report - annual statistics publication

$>$ Memorandum of Understanding - working agreement with solar thermal trade organizations

$>$ Workshops and seminars

\section{Country Members}

Australia

Austria

Belgium

Canada

China

Denmark

European Commission

\section{Sponsor Members}

European Copper Institute ECREEE

France
Germany
Italy
Mexico
Netherlands
Norway
Portugal

France

Italy

Mexico

Norway

Portugal

RCREEE

International Solar Energy Society
Slovakia

South Africa

Spain

Sweden

Switzerland

Turkey

United Kingdom

For more information on the IEA SHC work, including many free publications, please visit www.iea-shc.org. 


\section{Contents}

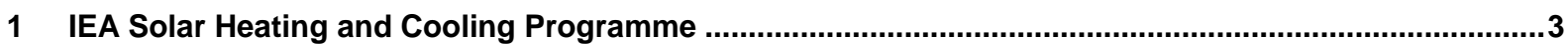

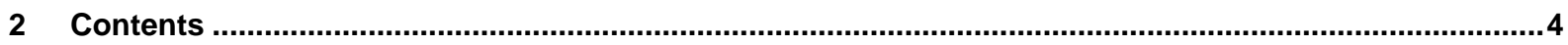

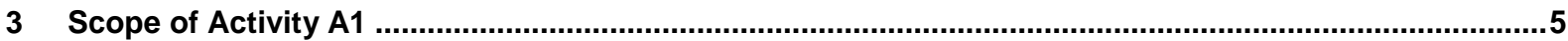

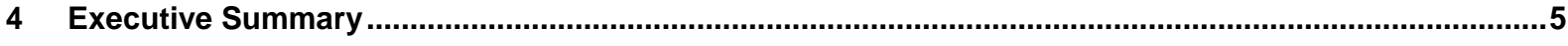

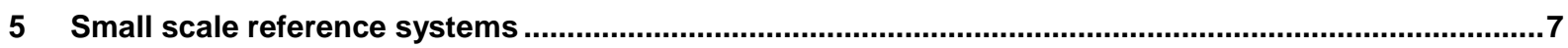

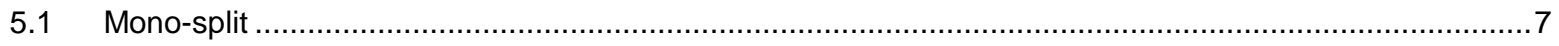

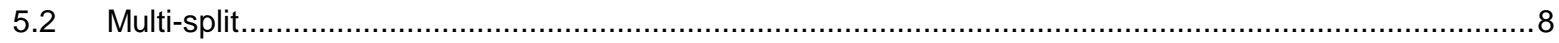

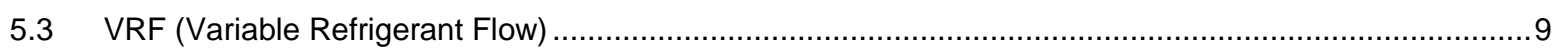

6 Definition on manufacture declared data for EER and SEER .........................................................12

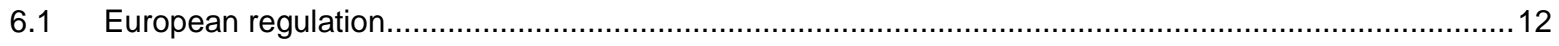

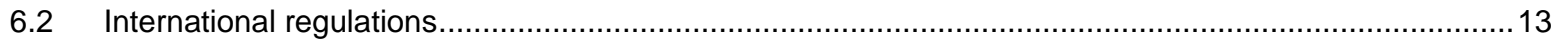

$7 \quad$ Parametric simulation study

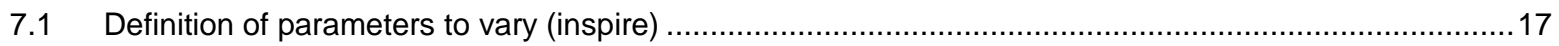

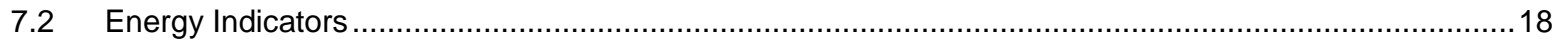

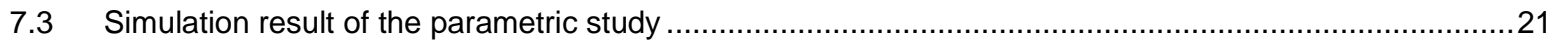

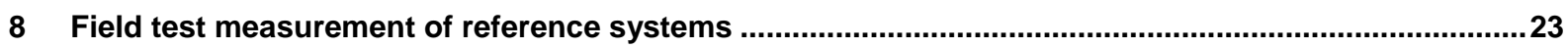

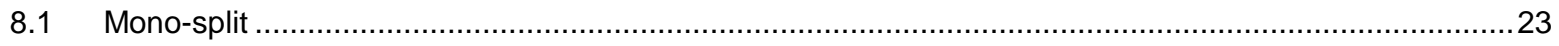

$8.2 \quad$ VRF

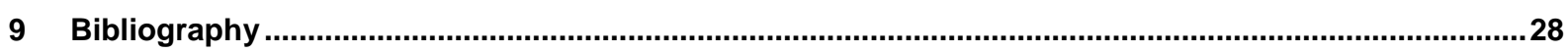

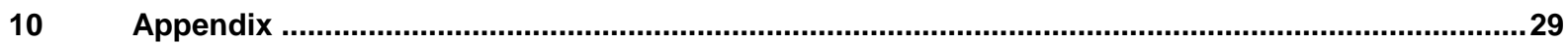

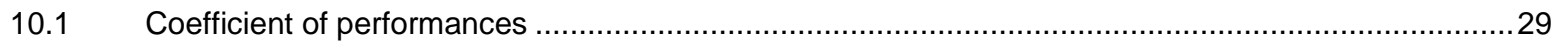

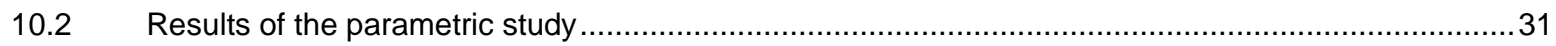




\section{Scope of Activity A1}

In this activity of SHC Task 53, a detailed description of typical conventional reference system is delivered. Market dominating small scale system types $(<10 \mathrm{~kW})$ for air-conditioning, cooling and heating for rooms are investigated and identified reference systems apply the mechanical compression method to treat the working fluid.

The reference system respect different European climate zones and with displaying and discussing the simulation results of a parametric study, the energy performance of the defined reference system is shown as a function of the room type and of the climate condition of the selected European Cities.

In addition, this system will depend on the range of energy use: cooling, space heating, domestic hot water.

Therefore, a set of reference systems will be selected and described on their technical performance level. Furthermore, this database permits in the Subtask B to make a comparison with new generation solar cooling and heating systems.

\section{Executive Summary}

The work of Subtask A covers horizontal activities related to subtasks B and C. Activity A1 aims at delivering a useful report on market available reference systems in the range up to around $100 \mathrm{~kW}$ of cooling capacity. Three different kinds of reference systems were detected - namely Mono-split, Multi-split and VRF (Variable Refrigerant Flow) systems and a brief description introduces their technical functionalities and components. Furthermore, this report displays as well selected laboratory measurement results of investigated reference systems conducted by SHC Task 53 participants. Herewith the Energy Efficiency Ratio (EERc) for cooling and the Coefficient of Performance (COPh) for heating are indicated as key energy performance indicators. Furthermore, European and international regulation are introduced for understanding manufacture declared energy system performance indicators. With the help of a comprehensive parametric study based on results of transient simulation, the SHC Task 53 participants present an overview of the annual energy performance depending on a mix of different application and climate regions. This database permits furthermore in the Subtask B to make a comparison with new generation solar cooling and heating systems. Finally, this report ends with showing up some field test data of operated Mono-split and VRF systems.

The SHC Task 53 A1 report is structured by four essential chapters:

- Chapter 3 - Small scale reference systems,

This chapter reports on three market dominating technical solution compressing and evaporating the working fluid for cooling and heating of buildings in the capacity range below $100 \mathrm{~kW}$ thermal. Herewith Mono-split, Multi-split and Variable Refrigerant Flow (VRF) system are technically described and at least a technical scheme of the main components and working fluid cycle is displayed.

- $\quad$ Chapter 4 - Definition of manufacture declared performance indicator

For efficiency rating of air conditioner products on the market different legislations and standards exits worldwide. In this chapter energy related performance indicators defined by European and International standard and regulation - like the seasonal energy efficiency ratio SEER - are introduced.

- $\quad$ Chapter 5 - Parametric study

This chapter contains information and a documentation of a parametric study of reference systems. With the help of the modelling and simulation work done in the European research project iNSPiRe ${ }^{1}$ a comprehensive parametric study has been carried out and the simulation results serve as the data base for quantifying and analyzing the impact of selected parameters on the annual energy performance of the reference system. Thus, this section provides knowledge and information about the energy performance of different reference system configuration for different building typologies in different European climate region. The economic assessment is not part of this D-A1 report, but nevertheless in Subtask $B$ further simulation work has been carried out and results of an economic assessment of new generation of solar cooling 1 iNSPiRe Project www.inspirefp7.eu The research leading to the results exposed has received funding from the European Commission's 7th
Framework Programme 2007-2013 under GA n 314461 . 
and heating systems can be found there - see Deliverable D_B.5 Technical report on simulations results and systems inter comparison. In this chapter information are given related to a) the defined technical configuration of the reference systems, b) the applied characteristics model of the coefficient performance for heating and c) simulation results by indicating key performance indicators.

- $\quad$ Chapter 6 - Field test measurement of reference systems

In the joint German research project EvaSolK [EvaSolK 2013], realized by the research institutes Fraunhofer-ISE, ILK Dresden and ZAE Bayern, different kinds of reference technologies were measured on test bench and in field test. Measurements results of operated Mono-split and VRF-system are displayed and analyzed.

\subsubsection{Contributing Authors}

Table 1: SHC Task 53 A1 report contributing authors and entities

\begin{tabular}{llll} 
ENTITIES & PERSONIN CHARGE & COUNTRY & CONTRIBUTION \\
\hline AIT & Tim Selke & Austria & $\begin{array}{l}\text { Coordinator, Activity Leader, } \\
\text { Author of Chapter } 2 \text { and } 5\end{array}$ \\
EURAC & Chiara Dipasquale & Italy & Chapter 5 / Contributing Author \\
ZAE & Richard Schex & Germany & Chapter 3, 6 / Contributing Author \\
TUM & Felix Loistl & Germany & Chapter 3 / Contributing Author \\
ILK Dresden & Carsten Heinrich & Germany &
\end{tabular}




\section{Small scale reference systems}

\subsection{Mono-split}

Mono-split systems include a single outdoor and a single indoor unit. Almost all Mono-split units on the market allow cooling and heating mode. Switching between cooling and heating mode is realized by a four-way-valve (see figure 1). Compared to Multi-split and VRF (Variable Refrigerant Flow)-Systems the expansion device is located in the outdoor unit. Outdoor units are prefilled with refrigerant, additional refrigerant charging during installation is only required in case of extra-long tube connection between in- and outdoor unit.

Cooling capacity ranges from about 1.5 up to $7 \mathrm{~kW}$, typical cooling capacities are $2.6,3.5$ and $5.2 \mathrm{~kW}$ (this corresponds to $9,000,12,000$ and 15,000 BTU/h).

R410A is widely used as refrigerant. To reduce direct greenhouse gas emissions, systems with refrigerants R32 (Daikin, Panasonic and Toshiba) and R290 propane (Godrej, Midea, Gree) have entered the market a few years ago.

Inverter controlled rotary compressors predominate also in low-budget products to achieve claimed efficiency ratios. Capillary tubes or electronic expansion valves are used as expansion devices depending on cooling capacity and price level.

\section{cooling mode}

\section{heating mode}
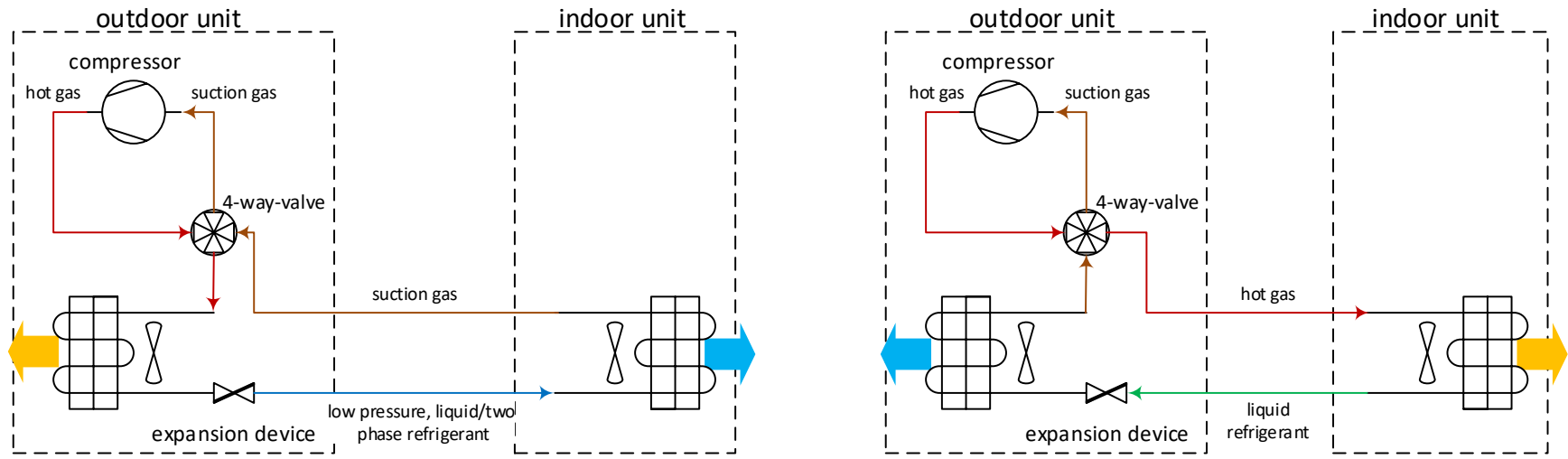

Figure 1: Mono-split system in cooling and heating mode

Mono-split units sold in Europe are covered by the eco-design regulation EU No 206/2012 (implementing directive 2009/125/EC). Efficiency is described as seasonal energy efficiency ratio (SEER) calculated according to EN 14825 . Energy labels from $\mathrm{A}+++$ down to $\mathrm{D}$ are defined. Minimum required SEER depends on Global warming potential or Greenhouse warming potential (GWP) of the applied refrigerant: 4.6 for refrigerants with GWP > 150 and 4.14 for refrigerants with GWP < 150. Available products achieve SEERs up to 9.5, corresponding to energy label $A_{+++}$(see Figure 2). 

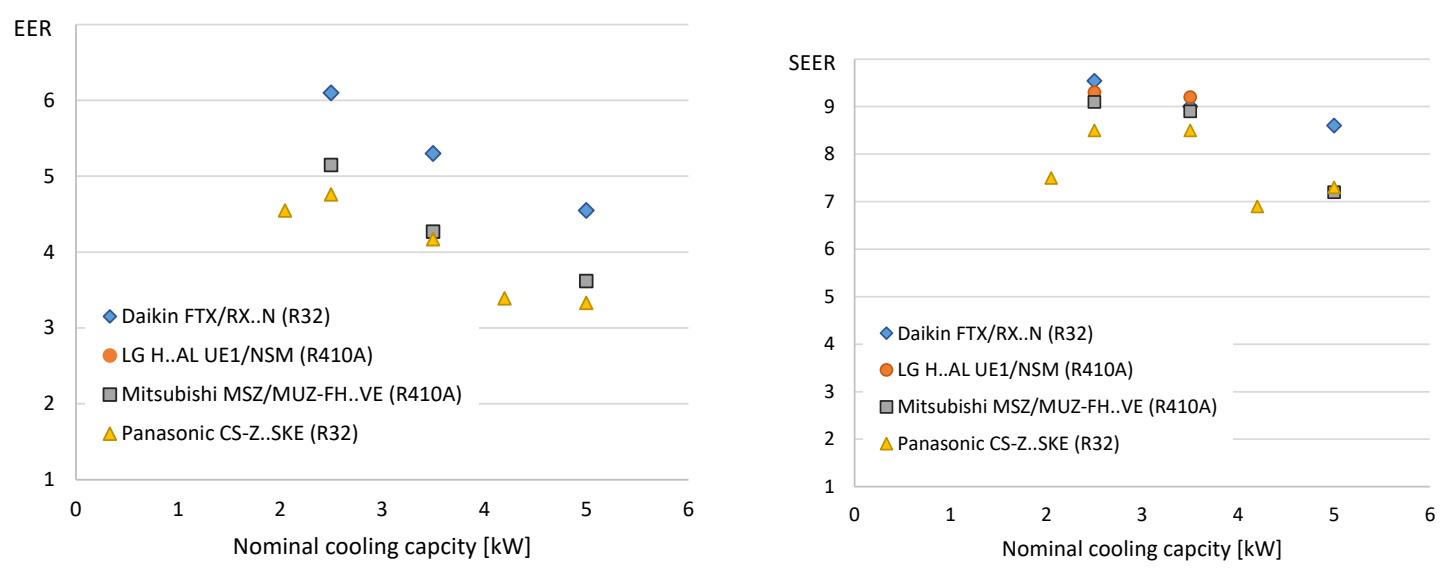

Figure 2: EER and SEER in cooling mode of different high efficient Mono-split units on the market

\subsection{Multi-split}

In Multi-split systems the technology of DX-air-conditioning systems employed in Mono-split systems is extended to applications where larger rooms or higher buildings cooling demands are to be covered. Instead of one outdoor unit and one indoor unit, larger outdoor units are connected to several indoor units. Usually each indoor unit is connected by an individual pair of refrigerant pipes to the outdoor unit (Figure 3). The entire system can operate in cooling or heating mode, with all indoor units operating in the same mode. In the past the systems were equipped with a single speed compressor, nowadays often inverter driven compressors are used.

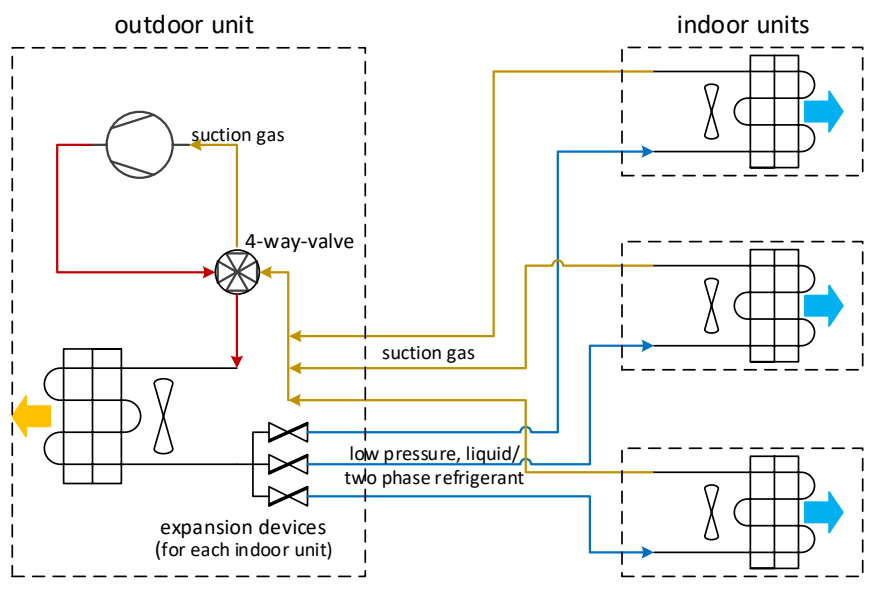

Figure 3: Multi-split System in cooling mode

Multi-split systems are applied for small up to middle size buildings with about 9 indoor units.

Typical applications are:

- Residential buildings

- Hotels

- Offices

Compared to VRF-Systems, as described in the following section 3.3, Multi-split systems are more limited in size, piping length and functional variability. 


\subsection{VRF (Variable Refrigerant Flow)}

VRF-Systems represent the latest level of development of Multi-split systems. These systems can react to the building load by varying the refrigerant mass flow. As in classical Multi-split systems, they consist of an outdoor unit and several indoor units which are positioned in the air-conditioned room. The outdoor units include the compressor, heat exchanger, expansion device, a four-way valve and some additional refrigeration components like an economizer. Each indoor unit is equipped with an individual expansion device allowing for control of the heating or cooling capacity locally. Also, they can ventilate and dehumidify. Regarding piping and heat transfer media there are different types of VRF-systems. The most common are twopipe and three-pipe air-to-air VRF-Systems.

Figure 4 shows a three-pipe system operating in cooling mode with its main components and devices. In this case, the heat exchanger of the outdoor unit works as a condenser while the heat exchangers of the indoor units act as evaporators.

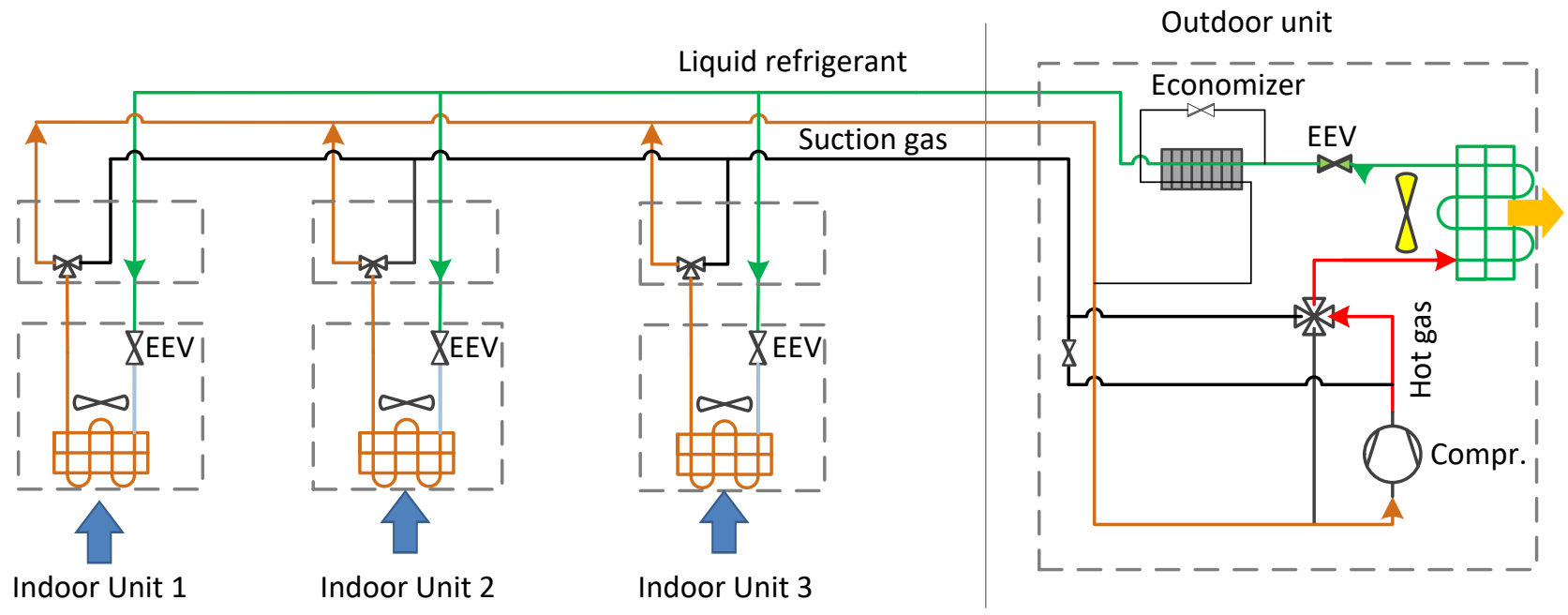

Figure 4: VRF-3-pipe-system in cooling mode.

The indoor units absorb the heat from the room by evaporating the refrigerant. The evaporation is controlled by the electronic expansion valve (EEV) of the indoor unit and by the compressor. The EEV regulates the degree of superheat at the evaporator outlet while the compressor is adjusted to ensure that the low pressure meets the target value. Refrigerant vapor reaches the compressor through the suction gas pipe. In the next step the vapor is compressed to a higher-pressure level. The pressurized, super-heated refrigerant (hot gas) is then led to the condenser where it is liquefied by rejecting the heat to the environment. The liquid refrigerant passes the economizer and returns to the indoor units. 


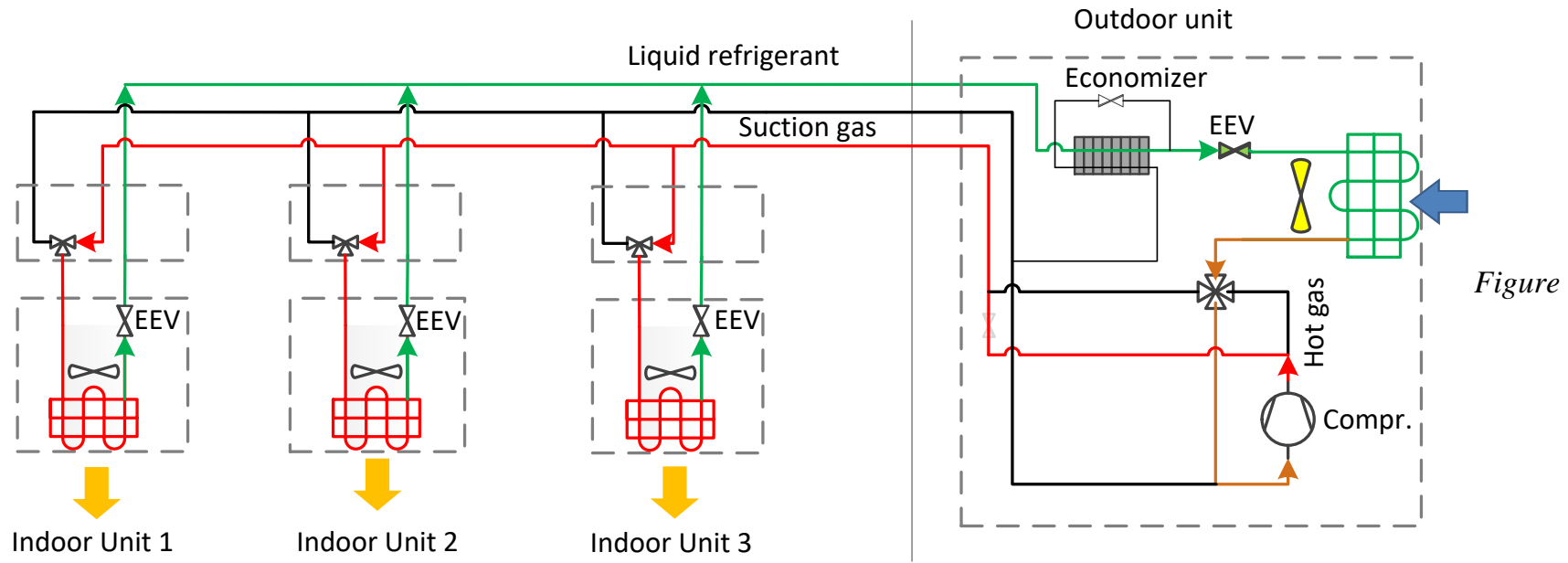

Figure 5: VRF-3-pipe-system in heating mode.

Figure Figure 5 clarifies the VRF-System working in heating mode. In this case the indoor units act as condensers. The electronic expansion valves of the indoor units are used for control of flow and sub-cooling of the condensed refrigerant at the condenser outlet. The liquefied refrigerant is led back to the outdoor unit where it is evaporated and compressed again. Control of the overall refrigerant flow is affected by the electronic expansion valve at the inlet of the evaporator. The compressor controls the low-pressure level to reach the target value.

The advantage of a three-pipe system is shown in Figure 6. A three pipe VRF-system is capable to operate in heat recovery mode by shifting energy from one room to another, i.e. heating and cooling is provided simultaneously. Figure 6 illustrates the following constellation, with dominating heating demand: Indoor Unit 1 is in cooling mode which means it absorbs heat, while the indoor units 2 and 3 are in heating mode. The heat exchanger in the outdoor unit works as an evaporator providing additional low-grade heat input to balance the overall heat flow.

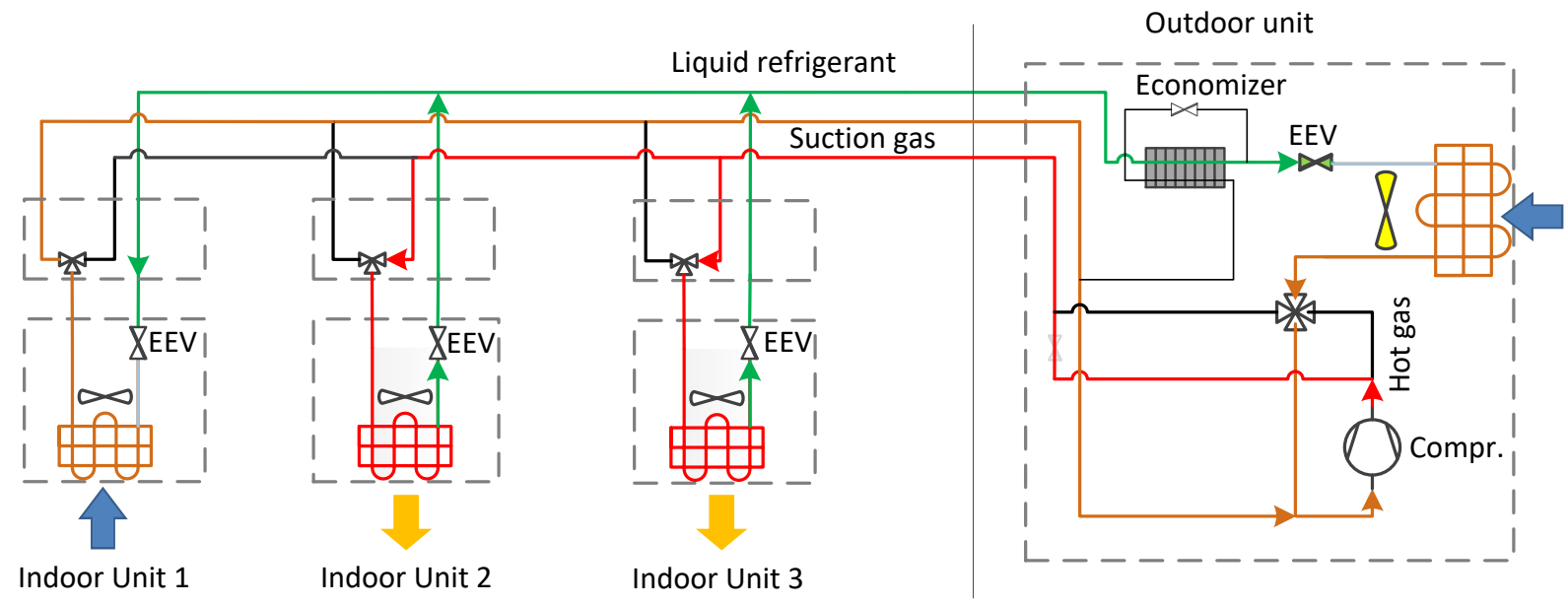

Figure 6: VRF-3-pipe-System in heat recovery mode

After being liquefied in indoor unit 2 and 3 the refrigerant partly flows to indoor unit 1 and partly to the outdoor unit. Indoor unit 1 directly takes advantage of the liquefied refrigerant in unit 2 and 3 and uses this refrigerant for absorbing heat from the room without contribution of the outdoor heat exchanger. The other part of the refrigerant evaporates in the outdoor heat exchanger. In the compressor the sum of evaporated gas is compressed again for the use in indoor unit 2 and 3 . The efficiency values of three different 3-pipe heat recovery VRF-systems are shown in Figure 7. The nominal values of the selected models are extracted from data provided by the manufacturers. The number indicates the model of the manufacturer (compare Table 1). 

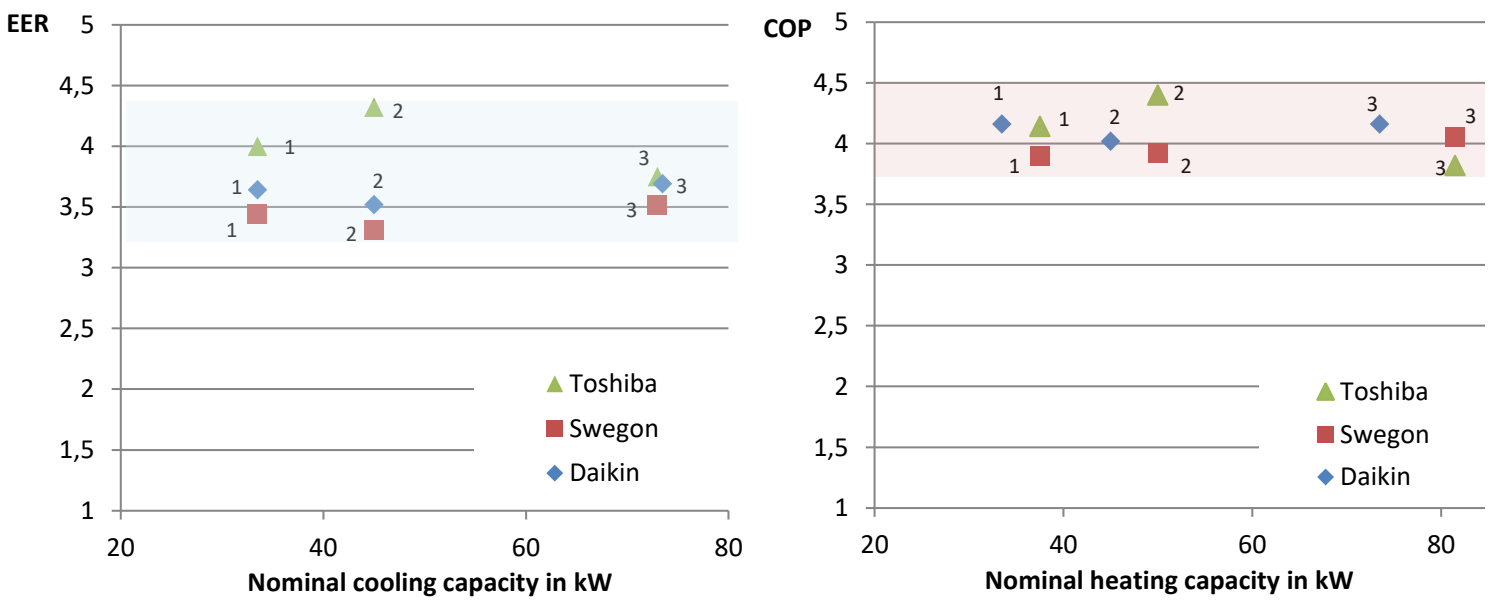

Figure 7: EER/COP of different VRF- 3-pipe-systems in dependence of the capacity.

Conditions: Cooling - Indoor $27^{\circ} \mathrm{C}$ DB, $19^{\circ} \mathrm{C}$ WB, outdoor $35^{\circ} \mathrm{C} \mathrm{DB}$;

Heating - Indoor $20^{\circ} \mathrm{C}$ DB, outdoor $7^{\circ} \mathrm{C} \mathrm{DB}, 6^{\circ} \mathrm{C}$ WB;

equivalent pipe length: 7.5 meter (Toshiba, Swegon), 5 meter (Daikin)

Full designation of the selected models for capacities 1, 2, and 3 are shown in Table 1.

Table 1: Chosen models of manufacturer for nominal efficiency values

\begin{tabular}{|l|c|c|c|}
\hline \multicolumn{1}{|c|}{ Manufacturer / No. } & 1 & 2 & 3 \\
\hline Swegon & AJYA108GALH & AJYA144GALH & AJYA234GALH \\
\hline Daikin & REYQ12T & REYQ16T & DE.REYQ26T \\
\hline Toshiba & MMY-MAP1204FT8-E & MMY-AP1614FT8-E & MMY-AP2614FT8-E \\
\hline
\end{tabular}

In many cases the same manufacturer model is used for a certain range of nominal capacities. Best performance is achieved when the model is applied for the minimal value of its specified capacity range.

Typical applications:

- Offices

- Educational facilities

- Commercial buildings

- Hospitals 


\section{Definition on manufacture declared data for EER and SEER}

\subsection{European regulation}

For efficiency rating of air conditioner products on the market different legislations and standards exits worldwide. The ecodesign regulation in Europe requires the labeling of air conditioning units $<12 \mathrm{~kW}$ cooling capacity to EU No. 206/2012. For air conditioning unit $>12 \mathrm{~kW}$ and Multi-split systems similar legislations are in preparation [SBZ 2015]. Calculation scheme will be similar.

According to EN 14825 the seasonal energy efficiency ratio for air to air systems is defined as:

$$
S E E R=\frac{Q_{C}}{Q_{C E}}
$$

The electrical energy consumption $Q_{C E}$ includes power consumption in active cooling mode, in standby and off mode and for crankcase heating.

$$
Q_{C E}=\frac{Q_{C}}{S E E R_{o n}}+H_{T O} \cdot P_{T O}+H_{S B} \cdot P_{S B}+H_{C K} \cdot P_{C K}+H_{O F F} \cdot P_{O F F}
$$

Here,

$$
\begin{array}{ll}
H_{T O}, H_{S B}, H_{C K}, H_{O F F} & \begin{array}{l}
\text { number of hours in mode: temperature control off, stand by, crankcase heating } \\
\text { and switched off }
\end{array} \\
P_{T O}, P_{S B}, P_{C K}, P_{O F F} & \begin{array}{l}
\text { power consumption in mode: temperature control off, stand by, crankcase } \\
\text { heating and switched off }
\end{array}
\end{array}
$$

Seasonal performance factor during active cooling mode $S E E R_{\text {on }}$ is calculated based on distribution of temperature levels, corresponding part load factors, efficiency and number of cooling hours:

$$
S E E R_{\text {on }}=\frac{\sum_{j=1}^{n} h_{j} \cdot \dot{Q}_{S C}\left(T_{j}\right)}{\sum_{j=1}^{n} h_{j} \cdot \frac{\dot{Q}_{S C}\left(T_{j}\right)}{E E R\left(T_{j}\right)}}
$$

Here,
$T_{\mathrm{j}} \quad$ temperature level

\begin{tabular}{|c|c|c|c|c|c|}
\hline - point & - hours & $\begin{array}{c}\text { part load } \\
\text { factor }\end{array}$ & $\begin{array}{l}\text { - indoor } \\
\text { temperature }\end{array}$ & $\begin{array}{c}\text { indoor rel. } \\
\text { humidity }\end{array}$ & \begin{tabular}{|c} 
outdoor \\
temperature
\end{tabular} \\
\hline - $\mathrm{A}$ & - 13 & - $100 \%$ & - $\quad 27,0^{\circ} \mathrm{C}$ & - $46 \%$ & - $35,0^{\circ} \mathrm{C}$ \\
\hline - $\mathrm{B}$ & - 63 & - $74 \%$ & - $27,0^{\circ} \mathrm{C}$ & - $46 \%$ & - $30,0^{\circ} \mathrm{C}$ \\
\hline - $\mathrm{C}$ & - 178 & - $47 \%$ & - $27,0^{\circ} \mathrm{C}$ & - $46 \%$ & - $25,0^{\circ} \mathrm{C}$ \\
\hline - $\mathrm{D}$ & - 225 & - $21 \%$ & - $\quad 27,0^{\circ} \mathrm{C}$ & - $46 \%$ & - $20,0^{\circ} \mathrm{C}$ \\
\hline
\end{tabular}
j temperature level index
n number of temperature levels
$h_{\mathrm{j}} \quad$ number of cooling hours of temperature level $\mathrm{j}$

Temperature levels, part load factors, and corresponding cooling hours are fixed and provided by EN 14825 - Appendix A. For the SEER value only 4 defined temperature levels $A, B, C, D$ are used (Table 1).

Tabelle 2: Relevant temperature level data required for SEER calculaction acording to EN14825 
The energy efficiency ratio at each temperature level EER(Tj) is measured according to EN 14511-3 (2013) and includes power input for fans of indoor and outdoor unit. Air conditioning units $<12 \mathrm{~kW}$ must be measured according to the calorimeter room procedure, units $>12 \mathrm{~kW}$ can be measured according to calorimeter room procedure or air enthalpy procedure.

\subsection{International regulations}

Seasonal performance indicators, analogous to the European SEER, are used worldwide for performance rating. Calculation schemes, temperature levels and corresponding operation hours vary according to considered region. In Table 2 an overview of international regulations for seasonal performance calculation is presented. Table 3 shows reference points and weighting factors for the integrated energy efficiency ratio (IEER) according to the American standards AHRI 340/360-2015. Due to the different calculation approach, American IEER-factor and European SEER-factor cannot be compared directly neither be interconverted.

Table 2: Survey about international regulations for seasonal performance calculation

\begin{tabular}{|l|l|l|}
\hline Region & Legislation / Standard & Remarks \\
\hline America & AHRI Standard 340/360-2015 & $\begin{array}{l}\text { for factory-made commercial and industrial unitary air-conditioning units } \\
\text { EER conditions: } \\
\text { indoor section air entering: dry-bulb 26,7 }{ }^{\circ} \mathrm{C} \text {, wet-bulb } 19,4^{\circ} \mathrm{C}=>64,3 \% \\
\text { rel. humidity } \\
\text { outdoor section (air cooled): dry-bulb } 35,0{ }^{\circ} \mathrm{C} \text {, wet-bulb } 23,9^{\circ} \mathrm{C} \\
\text { IEER (integrated energy efficiency ratio) }\end{array}$ \\
\hline America & $\begin{array}{l}\text { AHRI Standard 210/240-2008 } \\
\text { /with Addendum 1 and 2 (2012) }\end{array}$ & $\begin{array}{l}\text { for unitary air conditioners and air heaters } \\
\text { EER values must evaluated acc. to ANSI/ASHARE Standard } 37 \text { with } \\
\text { Appendices C and D }\end{array}$ \\
\hline Japan & JIS 9612:2013 & $\begin{array}{l}\text { for room air conditioners } \\
\text { cooling seasonal performance factor based on ISO 16358 }\end{array}$ \\
\hline Japan & JIS B 8616:2015 & for commercial air conditioners \\
\hline South Korea & KS C 9306 2011 & CSPF (Cooling Seasonal Performance Factor) based on ISO 16538 \\
\hline Australia & AS/MZS 3823-2013 & AEER \\
\hline China & GBT 17758-2010 & SEER \\
\hline
\end{tabular}

Integrated energy efficiency ratio IEER according to AHRI Standard 340/360-2015 is calculated by weighting efficiency at different part load conditions:

$$
I E E R=\sum_{j=A}^{D} w_{j} \cdot E E R_{j}
$$

Table 3: Temperature levels and relevant factors for IEEr caclualction accr. to AHRI 210/240 and 340/360 standard

\begin{tabular}{|c|c|c|c|c|c|c|}
\hline point & $\begin{array}{l}\text { weighting } \\
\text { factor w }\end{array}$ & $\begin{array}{l}\text { part load } \\
\text { factor }\end{array}$ & $\begin{array}{l}\text { indoor } \\
\text { temperature }\end{array}$ & $\begin{array}{l}\text { indoor rel. } \\
\text { humidity }\end{array}$ & $\begin{array}{l}\begin{array}{l}\text { outdoor } \\
\text { temperature } \\
\text { AHRI } 340 / 360\end{array} \\
\end{array}$ & $\begin{array}{l}\text { outdoor temperature AHRI } \\
210 / 240\end{array}$ \\
\hline A & 0.02 & $100 \%$ & $26.7^{\circ} \mathrm{C}$ & $50 \%$ & $35.0^{\circ} \mathrm{C}$ & $35.0^{\circ} \mathrm{C}$ \\
\hline B & 0.617 & $75 \%$ & $26.7^{\circ} \mathrm{C}$ & $50 \%$ & $27.5^{\circ} \mathrm{C}$ & $27.5^{\circ} \mathrm{C}$ \\
\hline C & 0.238 & $50 \%$ & $26.7^{\circ} \mathrm{C}$ & $50 \%$ & $20.0^{\circ} \mathrm{C}$ & $27.5^{\circ} \mathrm{C}$ \\
\hline D & 0.125 & $25 \%$ & $26.7^{\circ} \mathrm{C}$ & $50 \%$ & $18.3^{\circ} \mathrm{C}$ & $27.5^{\circ} \mathrm{C}$ \\
\hline
\end{tabular}


The Japanese cooling seasonal performance factor $F_{C S P}$ or the total cooling seasonal performance factor $F_{T C S P}$ including power consumption during inactive time, is based on calculation approach according to ISO 16358. It assumes full cooling load at 35 ${ }^{\circ} \mathrm{C}$ ambient temperature and zero cooling load at $20^{\circ} \mathrm{C}$ ambient temperature. Cooling load $L_{C}$ vs. ambient temperature $t_{A m b}$ is assumed to be linear distributed.

Here,

$$
\begin{gathered}
F_{C S P}=\frac{L_{C S T}}{C_{C S E}} \\
F_{T C S P}=\frac{L_{C S T}}{C_{C S E}+C_{I E A}}
\end{gathered}
$$

$$
\begin{array}{ll}
L_{C S T} & \text { seasonal cooling energy demand } \\
C_{C S E} & \text { seasonal energy consumption for cooling production } \\
C_{I E A} & \text { inactive energy consumption during cooling season } C_{I A E}=H_{i a} \cdot P_{i a}
\end{array}
$$

The seasonal cooling energy demand is calculated based on a reference ambient temperature bin hour distribution depending on outdoor temperature (see Table 4). The inactive reference hours $H_{i a}$ are $4077 \mathrm{~h}$.

$$
L_{C S T}=\sum_{j=1}^{m} L_{C}\left(t_{j}\right) \cdot n_{j}+\sum_{j=m+1}^{n} \phi_{f u l l}\left(t_{j}\right) \cdot n_{j}
$$

For the consumption calculation temperature effect and part load factor are considered:

$$
C_{C S E}=\sum_{j=1}^{m} X\left(t_{j}\right) \cdot P_{f u l l}\left(t_{j}\right) \cdot \frac{n_{j}}{F_{P L\left(t_{j}\right)}}
$$

Table 4: Reference outdoor temperature bin distribution acc. to ISO 16538

\begin{tabular}{|l|l|l|l|}
\hline bin number $\mathrm{j}$ & $\begin{array}{l}\text { outdoor } \\
\text { temperature } t_{j}\end{array}$ & $\begin{array}{l}\text { fractional bin } \\
\text { hours }\end{array}$ & $\begin{array}{l}\text { reference bin } \\
\text { hours } n_{j}[\mathrm{~h}]\end{array}$ \\
\hline 1 & $21^{\circ} \mathrm{C}$ & 0.055 & 100 \\
\hline 2 & $22^{\circ} \mathrm{C}$ & 0.076 & 139 \\
\hline 3 & $23^{\circ} \mathrm{C}$ & 0.091 & 165 \\
\hline 4 & $24^{\circ} \mathrm{C}$ & 0.108 & 196 \\
\hline 5 & $25^{\circ} \mathrm{C}$ & 0.116 & 210 \\
\hline 6 & $26^{\circ} \mathrm{C}$ & 0.118 & 215 \\
\hline 7 & $27^{\circ} \mathrm{C}$ & 0.116 & 210 \\
\hline 8 & $28^{\circ} \mathrm{C}$ & 0.100 & 181 \\
\hline 9 & $29^{\circ} \mathrm{C}$ & 0.083 & 150 \\
\hline 10 & $30^{\circ} \mathrm{C}$ & 0.066 & 120 \\
\hline 11 & $31^{\circ} \mathrm{C}$ & 0.041 & 75 \\
\hline 12 & $32^{\circ} \mathrm{C}$ & 0.019 & 35 \\
\hline 13 & $33^{\circ} \mathrm{C}$ & 0.006 & 11 \\
\hline 14 & $34^{\circ} \mathrm{C}$ & 0.003 & 6 \\
\hline 15 & $35^{\circ} \mathrm{C}$ & 0.002 & 4 \\
\hline total & & & 1817 \\
\hline
\end{tabular}

Required measurement points for variable capacity units are full and half cooling capacity at $35{ }^{\circ} \mathrm{C}$ ambient temperature $\phi_{\text {full }}(35), \phi_{\text {half (35) }}$ and the corresponding power consumption $P_{\text {full }}(35), P_{\text {half }}(35)$. The following parameters indicate optional measurement points. In case of no measurement results are available the default value is used:

$\phi_{\min }(35) \quad$ minimum cooling capacity at $t_{A m b}=35^{\circ} \mathrm{C}$, default: $\phi_{\min }(29) / 1.077$

$P_{\min }(35)$ power consumption at minimum capacity at $t_{A m b}=35^{\circ} \mathrm{C}$, default: $P_{\min }(29) / 0.914$

$\phi_{\text {half }}(29) \quad$ half cooling capacity at $t_{A m b}=29^{\circ} \mathrm{C}$, default: $\phi_{\text {half }}(35) \cdot 1.077$

$P_{\text {half }}$ (29) power consumption at half capacity at $t_{A m b}=29^{\circ} \mathrm{C}$, default: $P_{\text {half }}(35) \cdot 0.914$

$\phi_{\min }(29) \quad$ minimum cooling capacity at $t_{A m b}=29^{\circ} \mathrm{C}$

$P_{\min }$ (29) power consumption at minimum capacity at $t_{A m b}=29^{\circ} \mathrm{C}$

Comparing SEER based on EN 14825 and FTCSP based on ISO 16538 several similarities in calculation approach can be identified. Both methods based on a detailed temperature distributed calculation scheme and both considered the power 
consumption during inactive time. Comparing temperature distribution, inactive hours and cooling load characteristic (see Figure 8) European SEER will result in higher values compared to FTCSP. AHRI Standard 340/360-2015 uses a much more simplified calculation approach. Results are not comparable to SEER and FTCSP.

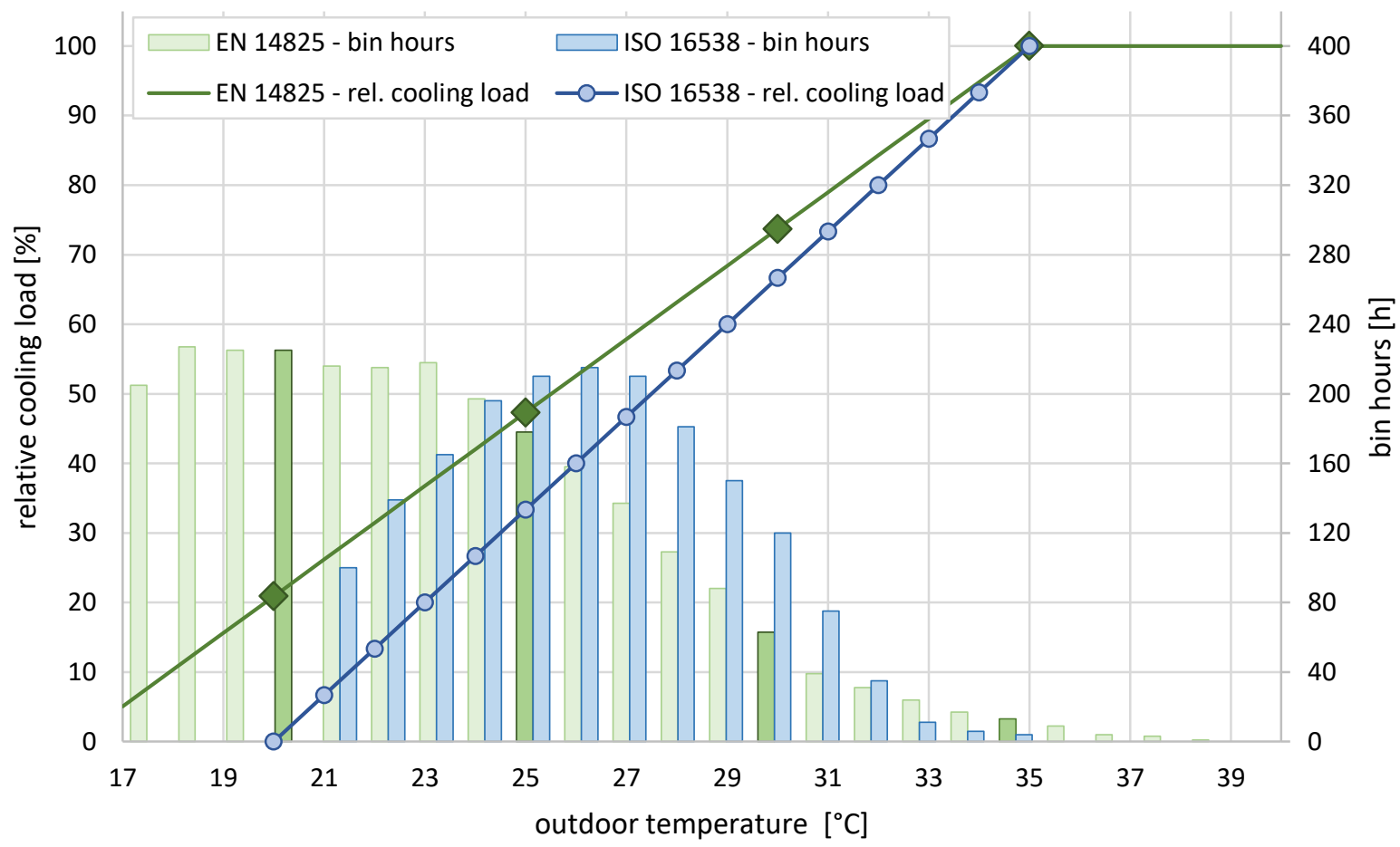

Figure 8: Bin hours and relative cooling load according to EN 14825 and ISO 16538 [EN 1825, ISO 1538, SEAD AC] 


\section{Parametric simulation study}

The SHC Task 53 activity group A1 concluded that a parametric study based on manifold modelling and simulation variants is a sufficient method to quantify, to analyze and to assess the annual energy performance of reference systems. This section provides complementary information about energy performance indicators of different reference system configuration in the range of $10 \mathrm{~kW}$ cooling. With the help of modelling and simulation work done in the European research project iNSPiRe ${ }^{2}$ the SHC Task 53 benefits from the applied method, the definition of reference systems and simulation results. Thus, this section contains text passages, illustration and results from the European project iNSPiRe taken from D6.3a Performance of Studied Systemic Renovation Packages - Methods. Detailed information and official reports of the iNSPiRe project can be found on the official website - see http://inspirefp7.eu. With respect to the focus of SHC Task 53 work plan this D-A1 report only addresses selected modelling variants and simulation results from this European project.

Within SHC Task 53 the definition of the parametric study comprises following categories:

- Climate: 3 different European sites (Moderate, hot/humid and hot/dry)

- Buildings: 3 different categories of buildings (SFH, MFH, OR)

- Energy demand: heating, cooling, domestic hot water and electricity demand

- Hot / cold water distribution system: 3 different supply water temperature levels (fan-coil, radiators + split units, radiant panel)

- Reference energy systems: Public electric grid, A/W or W/W HP, NGCB

Where:

- SFH: Single-Family House

- MFH: Multi-Family House

- OR: Office room

- DHW: Domestic hot water preparation

- A/W HP: Air to Water reversible heat pump (air-coupled)

- WN HP: Water to Water reversible heat pump (ground-coupled)

- NGCB: Natural gas condensing boiler

The chapter contains detailed documentation of the parameter variants, like a) the defined technical configuration of the reference systems, $b$ ) the applied characteristics model of the coefficient performance for heating and c) simulation results by indicating key performance indicators like Seasonal Performance Factor (SPF).

The energy performance of the reference system in operation has been calculated by applying transient system simulation ${ }^{3}$. For further investigation and comparison with next generation heating and cooling systems, key performance indicators should be calculated. Proposed key performance indicators are:

- Heating demand

- Cooling demand

- DHW demand

- Electricity demand (only HVAC)

- Final Energy

- Energy Efficiency Ratio (EER thermal, electric $_{\text {) }}$

- Seasonal Energy Efficiency Ratio (SEERthermal, electric)

- Primary energy demand (PE)

- $\quad$ CO2 Emission
$[\mathrm{kWh} / \mathrm{a}]\left[\mathrm{W} / \mathrm{m}^{2}\right]$

[kWh/a] $\left[\mathrm{W} / \mathrm{m}^{2}\right]$

$[\mathrm{kWh} / \mathrm{a}]\left[\mathrm{W} / \mathrm{m}^{2}\right]$
$[\mathrm{kWh} / \mathrm{a}]\left[\mathrm{W} / \mathrm{m}^{2}\right]$

$\begin{array}{lll} & {[\mathrm{kWh} / \mathrm{a}]} \\ & {[-]} & \\ {[-]} & \\ & {[\mathrm{kWhPE} / \mathrm{a}]} \\ & & {[\mathrm{tCO} 2 / \mathrm{a}]}\end{array}$

\footnotetext{
2 iNSPiRe Project www.inspirefp7.eu The research leading to the results exposed has received funding from the European Commission's 7th Framework Programme 2007-2013 under GA n 314461.

${ }^{3}$ Simulation environment TRNSYS 17, see http://trnsys.de/docs/trnsys/trnsys18_Neuheiten_en.htm
} 


\subsection{Definition of parameters to vary (inspire)}

With respect to the technical system scope of SHC Task 53, the reference system configuration for covering the energy demand for heating, cooling and domestic hot water (DHW) in the small thermal capacity range has been defined. The reference system is composed of a generation system, a distribution system, a storage for DHW, a buffer storage for heating and cooling distribution. This reference system definition is the basis for the simulation of different configurations for different building typologies by varying components sizes and control set points.

The generation system is considered with three variants: a) air to water heat pumps (A/W HP), b) ground source heat pumps (G/W HP) and c) gas boilers and split unit (see Figure 9).

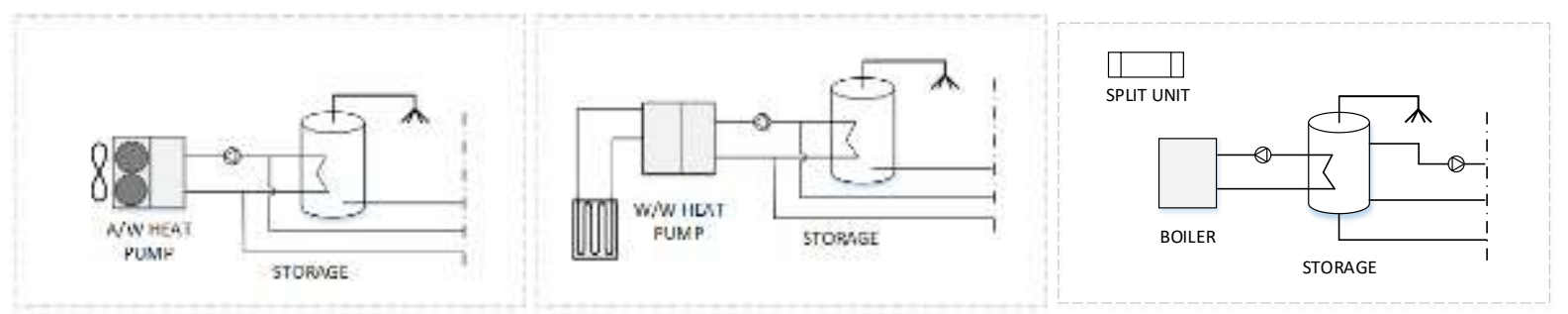

Figure 9 - Generation unit solutions. Where:

left) air to water heat pumps (A/W HP), middle) ground source heat pumps (G/W HP) and right) gas boilers and Split-System (Source: iNSPiRe D6.3 Report)

The modelling of the generation unit in operation is a key point. The energy efficiency of a heat pump is a function of the evaporator and of the condensing temperature level. For the heat pump technology, the Energy Efficiency Ratio (EER) indicates the efficiency in cooling mode and the Coefficient of Performance (COP) is used to indicate the energy efficiency in heating mode. Figure 17 - see Appendix - displays the COP for an Air to Water Heat Pump as a function of the water temperature at condensing and evaporator sides. The used characteristic curves representing the energy efficiency for an a) Air to Water Heat pump, b) Water to Water Heat Pump and c) Condensing Gas Boiler in the heating and cooling mode are displayed in Figure 17 till Figure 20.

Furthermore, the parametric study considers three different typologies of buildings, i.e. a) Single-Family House, b) MultiFamily House and c) Office room. A detail description of each model can be found in the report D2.1c Simulation Results of Reference Buildings of the iNSPiRe project.

General the simulation model for the Single-Family House (SFH) has a fixed geometry for all the climates and periods of construction. The building model is composed of two storeys with a total of area of $100 \mathrm{sqm}$ (2 zones are modelled and simulated and an overhang due to the roof has been modelled. The glazing ratio changes according to the façade orientation: a) for the south façade it amounts to $20 \%$, b) for the north façade around $10 \%$ and c) for the east and west façade around $12 \%$. Four different qualities of the thermal building envelope mainly respecting the U-values for the different external building elements - like roof, external walls, etc. - are modelled and this leads to four different energy demands for heating, i.e. 15, 25, 45 and $70 \mathrm{kWh}$ per year and area.

The second reference building typology represents a small multi-family house (sMFH). This reference building has two apartments per floor with an useful area of $50 \mathrm{sqm}$ per apartment and an individual staircase located inside the building envelope. The building model includes two zones per apartment, plus the staircase zone. Three floors have been simulated, and for buildings with more than 3 floors, the consumption of all intermediate floors is assumed to be the same as the midfloor. A glazing ratio of $20 \%$ for the north and south facades has been defined according to the most common s-MFHs. For the multi-family house three different qualities of the thermal building envelopes are modelled and this leads to three different energy demands for heating, i.e. 25, 45, $70 \mathrm{kWh}$ per year and area. 
The office building (OR) model has six thermal zones: two middle office rooms with one external wall and one office room in each corner of the building with two external walls. All internal walls are assumed to be adiabatic. The middle office rooms could be multiplied in post-processing to obtain results for the whole building, and the number of floors is five. All office rooms are of the same size and shape. With respect to different construction periods, different qualities of the thermal building envelopes are modelled. A glazing ratio of $30 \%$ is defined in the building model. With respect to the energy standard of the building envelope, the heating energy levels were assumed to be 25 and $45 \mathrm{kWh}$ per year and area.

Regarding the energy distribution system, the model takes also two different technical solutions into account. For controlling the room temperature in winter and summer a fan-coil system and a radiant floor and/or ceiling is modelled by means of different supply temperature levels.

For analyzing the impact of the climate on the cooling and heating demand three different European location have been selected representing a) moderate, b) hot/humid and hot/dry climate condition in Europe. The weather data records from Stuttgart, Rome and Madrid were generated by Meteonorm v6.1.

Table 5 is an overview on all variants of the parametric study which have been selected and taken from the iNSPiRe database.

Table 5: Parametric variants for the simulation based study

\begin{tabular}{|l|l|l|}
\hline Parametric variables & Number & Values \\
\hline Location & 3 & Stuttgart; Rome; Madrid \\
\hline \multirow{3}{*}{ Building heating demand levels } & SFH 4 & $15,25,45,70 \mathrm{kWh} / \mathrm{m} 2 / \mathrm{y}$ \\
\cline { 2 - 3 } & MFH 3 & $25,45,70 \mathrm{kWh} / \mathrm{m} 2 / \mathrm{y}$ \\
\cline { 2 - 3 } & Office 2 & $15 ; 45 \mathrm{kWh} / \mathrm{m} 2 / \mathrm{y}$ \\
\hline Heating and Cooling system & 3 & A/W HP, GWHP, Gas boiler, Split-System \\
\hline Radiant ceiling supply temperature & Winter & $35^{\circ} \mathrm{C}$ \\
\cline { 2 - 3 } & Summer & $15^{\circ} \mathrm{C}$ \\
\hline \multirow{2}{*}{ Fan coils supply temperature } & Winter & $45^{\circ} \mathrm{C}$ \\
\cline { 2 - 3 } & Summer & $7^{\circ} \mathrm{C}$ \\
\hline
\end{tabular}

\subsection{Energy Indicators}

Key performance indicators for all different defined reference systems were fixed and calculated for assessing the energy performance. The chosen energy performance indicators are:

- SPF_DHW (only HP); Seasonal Performance Factor for domestic hot water preparation [-]

- SPF_HEAT (only HP); Seasonal Performance Factor for heating [-]

- $\quad$ SPF_COOL (only HP); Seasonal Performance Factor for cooling [-]

- $\quad \mathrm{PE}$ specific annual primary energy consumption $\left[\mathrm{kWhPE} / \mathrm{m}^{2} / \mathrm{y}\right]$

- PER primary energy ratio [-]

- FET final thermal energy consumption $\left[\mathrm{kWhth} / \mathrm{m}^{2} / \mathrm{y}\right]$

- FEE final electric energy consumption $\quad\left[\mathrm{kWhel} / \mathrm{m}^{2} / \mathrm{y}\right]$

Generally, the Seasonal Performance Factor (SPF) is defined as the ratio of the thermal output of the heat pump unit to the effective electrical energy input to the unit for a steady state operating condition. In this context different SPF for covering the demand for heating, cooling and domestic hot water are considered:

$$
\begin{gathered}
S P F_{D H W}=Q_{D H W} / E_{D H W} \\
S P F_{H E A T}=Q_{H} / E_{H} \\
S P F_{C O O L}=\left(Q_{C}\right) /\left(E_{C}\right)
\end{gathered}
$$


Where is:

- QDHW: Heat delivered to cover the domestic hot water demand

- $Q_{\text {H: }}$ Heat delivered to cover the heating demand

- Qc: Heat extracted to cover the cooling demand

- EDHW: Electricity input to operate the DHW generation and distribution system

- $E_{\mathrm{H}}$ : Electricity input to operate the heating generation and distribution system

- Ec: Electricity input to operate the cooling generation and distribution system

FINAL ENERGY USE: The final energy use/consumption equals all energy supplied to operate the heating, cooling and air conditioning (HVAC) system including the distribution system for covering the energy building demand (heating, cooling, domestic hot water and ventilation). In the context of the parametric study the final energy is electricity and gas delivered by the public infrastructure.

PRIMARY ENERGY USE: For comparison of systems and technologies with respect to their environmental impact, the primary energy PE use is a key indicator. The primary energy use provides information on the consumption of non-renewable energy sources for the provision of useful energy output of the HVAC system operation. Note that this PE use does not account for the production, distribution, installation and end-of-life disposal of the HVAC system itself. It is a figure which considers the depletion of limited energy resources contained in e.g. fossil fuels.

CUMULATIVE ENERGY DEMAND (CED), non-renewable: For the calculation of this figure, the CEDNRE is used. It quantifies the non-renewable primary energy used to provide the final energy, including the energy used for construction of the electric grid and power plants. This indicator accounts for the primary energy from fossil, nuclear and primary forest resources (i.e. original forests that are destroyed and replaced by farmland) defined in terms of primary energy to final energy kWhPE/kWhFE.

$$
P E=F E * C E D_{N R E}
$$

For calculating the non-renewable primary energy used for operation the reference system following conversion factor were applied.

Table 6: CED $\mathrm{NRE}$ for different energy carriers (Malenkovic)

\begin{tabular}{|c|l|}
\hline Energy carrier & CEDNRE [kWhPE/kWhFE] \\
\hline Electricity & 2.878 \\
\hline Gas & 1.194 \\
\hline Oil & 1.271 \\
\hline
\end{tabular}

PRIMARY ENERGY RATIO: The analogue calculation approach used for the SPF definition can be used for the calculation of the primary energy ratio PER. In this case, the PE is used instead of the FE as denominator. This allows to compute a performance figure that comprehends all the different energy uses that cannot be summed up. 


$$
\begin{gathered}
P E R_{D H W}=Q_{D H W} / P E_{D H W} \\
P E R_{H E A T}=Q_{H} / P E_{H} \\
P E R_{C O O L}=\left(Q_{C}\right) /\left(P E_{C}\right) \\
P E R_{\text {tot }}=\left(Q_{D H W}+Q_{H}+Q_{C}\right) /\left(P E_{D H W}+P E_{H}+P E_{C}\right)
\end{gathered}
$$

\subsection{Simulation result of the parametric study}

168 variants of simulation runs have been selected in the framework of SHC Task 53 to display and to assess the energy performance of the specified reference system configuration. The simulation results are extracted from the public database accessible by the official web site of the iNSPiRe project. All results of the 168 simulation variants are listed in Table 9 , Table 10 and Table 11 of the Appendix.

In this section only, a reduced set of results is displayed and discussed. In particular, the simulation and calculation results for

\begin{tabular}{|c|c|c|c|c|c|c|c|c|c|}
\hline & \multicolumn{2}{|c|}{ sMulti-Family-House } & $\begin{array}{r}\text { SPF_DHW } \\
\text { (only HP) }\end{array}$ & $\begin{array}{l}\text { SPF_HEAT } \\
\text { (only HP) }\end{array}$ & $\begin{array}{c}\text { SPF_COOL } \\
\text { (only HP) }\end{array}$ & $\begin{array}{c}\text { PE } \\
\text { primary } \\
\text { energy } \\
\text { consumption }\end{array}$ & $\begin{array}{c}\text { PER } \\
\text { primary } \\
\text { energy } \\
\text { ratio }\end{array}$ & $\begin{array}{c}\text { FET final } \\
\text { thermal } \\
\text { energy } \\
\text { consumption }\end{array}$ & $\begin{array}{c}\text { FEE final } \\
\text { electric energy } \\
\text { consumption }\end{array}$ \\
\hline \multirow{6}{*}{ Stuttgart } & AWHP & radiant ceiling & 2,3 & 3,2 & 3,8 & 83,4 & 1,0 & 0,0 & 29,0 \\
\hline & & fan coils & 2,3 & 2,2 & 2,2 & 103,3 & 0,8 & 0,0 & 35,9 \\
\hline & GWHP & radiant ceiling & 2,2 & 3,4 & 4,5 & 80,2 & 1,1 & 0,0 & 27,9 \\
\hline & & fan coils & 2,2 & 2,3 & 2,6 & 98,5 & 0,8 & 0,0 & 34,2 \\
\hline & gas boiler & radiant ceiling & 61,1 & 68,9 & 5,2 & 117,8 & 0,7 & 89,5 & 3,9 \\
\hline & & fan coils & 60,1 & 44,3 & 5,4 & 109,6 & 0,7 & 82,1 & 4,1 \\
\hline \multirow{6}{*}{ Rome } & AWHP & radiant ceiling & 2,6 & 3,6 & 3,7 & 100,0 & 1,2 & 0,0 & 34,7 \\
\hline & & fan coils & 2,6 & 2,4 & 1,8 & 126,0 & 0,8 & 0,0 & 43,8 \\
\hline & GWHP & radiant ceiling & 2,3 & 3,5 & 4,3 & 100,0 & 1,2 & 0,0 & 34,7 \\
\hline & & fan coils & 2,3 & 2,4 & 2,3 & 123,5 & 0,8 & 0,0 & 42,9 \\
\hline & gas boiler & radiant ceiling & 71,1 & 71,8 & 5,0 & 140,5 & 0,8 & 97,4 & 8,5 \\
\hline & & fan coils & 69,9 & 49,9 & 5,2 & 124,3 & 0,8 & 84,2 & 8,3 \\
\hline \multirow{6}{*}{ Madrid } & AWHP & radiant ceiling & 2,5 & 3,4 & 3,5 & 110,0 & 1,1 & 0,0 & 38,2 \\
\hline & & fan coils & 2,5 & 2,4 & 2,3 & 133,8 & 0,8 & 0,0 & 46,5 \\
\hline & GWHP & radiant ceiling & 2,3 & 3,5 & 4,3 & 104,2 & 1,2 & 0,0 & 36,2 \\
\hline & & fan coils & 2,3 & 2,4 & 2,8 & 125,7 & 0,9 & 0,0 & 43,7 \\
\hline & gas boiler & radiant ceiling & 68,4 & 70,0 & 4,7 & 147,7 & 0,8 & 100,9 & 9,5 \\
\hline & & fan coils & 67,4 & 47,7 & 4,9 & 131,5 & 0,8 & 87,7 & 9,4 \\
\hline
\end{tabular}
the small Multi-Family House located in Stuttgart, Rome and Madrid and equipped with different technical solution for covering the heating, cooling and domestic hot water demand are listed in Table 7.

Table 7: Results of the parametric study for sMulti-Family houses with the energy label $45 \mathrm{kWh} / \mathrm{m}^{2} / \mathrm{y}$ 


\section{Summary and findings}

- The energy systems are designed to cover the energy demand for heating, cooling and domestic hot water preparation for a small Multi-Family house located virtually in three different climates regions across Europe (Stuttgart, Rome and Madrid).

- Both reference systems based on heat pump technology (A/W HP and G/W HP) require only electricity as final energy. The gas boiler is supplied by gas and the Split-unit system is operated by electricity. The warmer the climate the more use of final energy is indicated.

- The usage of radiant ceilings provided by lower supply temperatures is more energy efficient in terms of the annual final energy consumption than the fan coil equipment.

- The seasonal performance factor (SPF) for preparing domestic hot water by using heat pump technology is calculated with values in the range of 2.2 to 2.6, i.e. there is no significant difference identified. The annual profiles of the ambient temperature effects the SPF only a little. For the natural gas boiler, SPF values between 60 and 70 are quantified.

- Regarding the SPF values for cooling, a range from 2.2 up to 5.4 for a Multi-family house located in Stuttgart, Rome and Madrid is calculated. Thus, there is a significant difference in terms of energy efficient operation. The Split-unit improves the SPF for cooling

- Regarding the SPF values for heating, a range from 2.2 up to 3.6 for a Multi-family house located in Stuttgart, Rome and Madrid is calculated.

- The usage of primary energy is indicated with values in the range of 77 to 146 . The heat pump-based reference systems perform better than the gas boiler plus a Split-unit in terms of primary energy consumption. 


\section{Field test measurement of reference systems}

In the joint German research project EvaSolK [EvaSolK 2013], realized by the institutions Fraunhofer-ISE, ILK Dresden and ZAE Bayern prospects and limit of solar cooling technologies were investigated compared reference technologies were evaluated. Different kind of reference technologies were measured on test bench and in field test. Results for two different Mono-split and a VRF-system are summarized below.

\subsection{Mono-split}

Two different Mono-split air conditioning units have been investigated experimentally. Both units have been initially tested on a test bench and afterwards in a field test for at least one cooling period according to DIN V 18599. Measurements include power consumption of indoor and outdoor unit. Characteristic data and conditions of field test are summarized in Table 8.

Table 8: Description of the two Mono-split units used in field test

\begin{tabular}{|l|l|l|}
\hline & budget & brand supplier \\
\hline nominal cooling capacity & 2,65 & 5,0 \\
\hline nominal EER & 3,23 & $3,42 a$ \\
\hline compressor type & fix speed & inverter (variable speed) \\
\hline refrigerant & R410A & R410A \\
\hline application of field test & office comfort air conditioning & office comfort air conditioning \\
\hline test site & ILK Dresden & ZAE Bayern \\
\hline period of collected data & $\begin{array}{l}\text { July 2011 - October 2011 and } \\
\text { August 2012 - September 2012 b }\end{array}$ & June 2012-August 2012 \\
\hline $\begin{array}{l}\text { SEER based on accumulated cooling } \\
\text { generation and energy consumption }\end{array}$ & 3.47 & 4.68 \\
\hline
\end{tabular}

a) EER of $5.0 \mathrm{~kW}$ unit, same type series but nominal $2.5 \mathrm{~kW}$ cooling capacity results in EER $=4.63$

b) Measured period between April 2012 and July 2012 was removed due to mal function resulting from a refrigerant leakage at the mass flow rate sensor flange
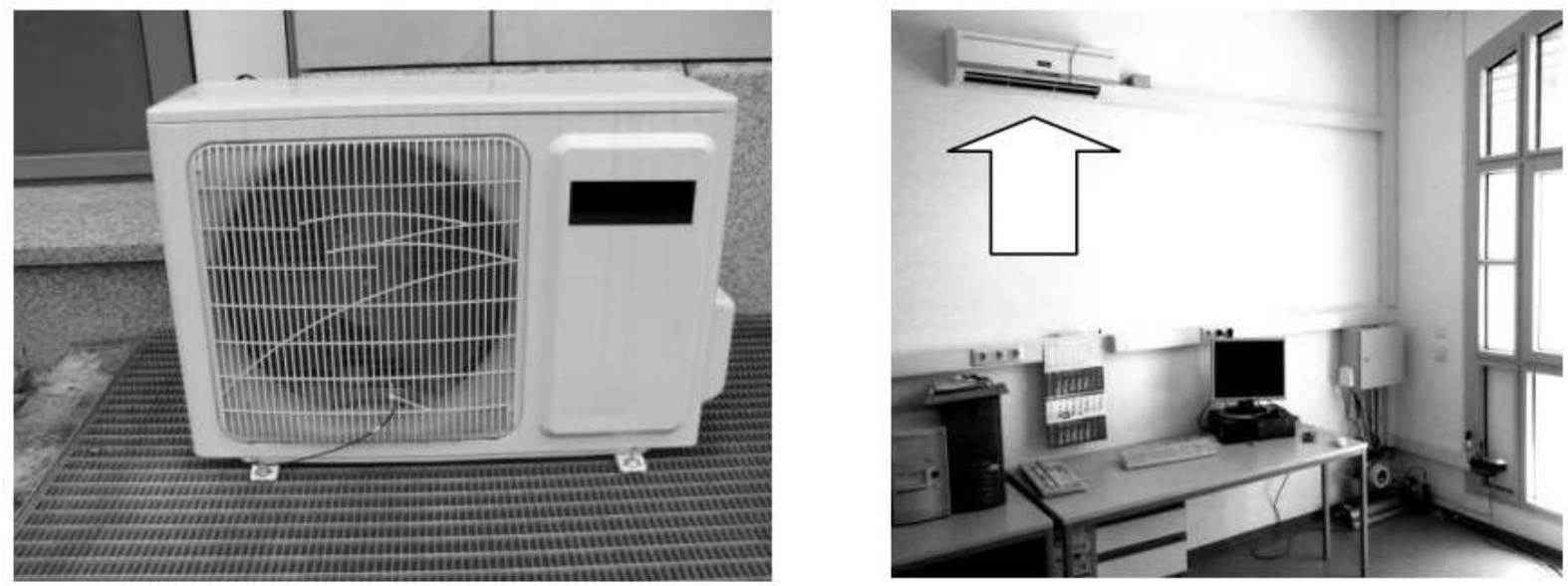

Figure 10: Installation of budget Mono-split-unit at ILK Dresden [EvaSolK 2013] 

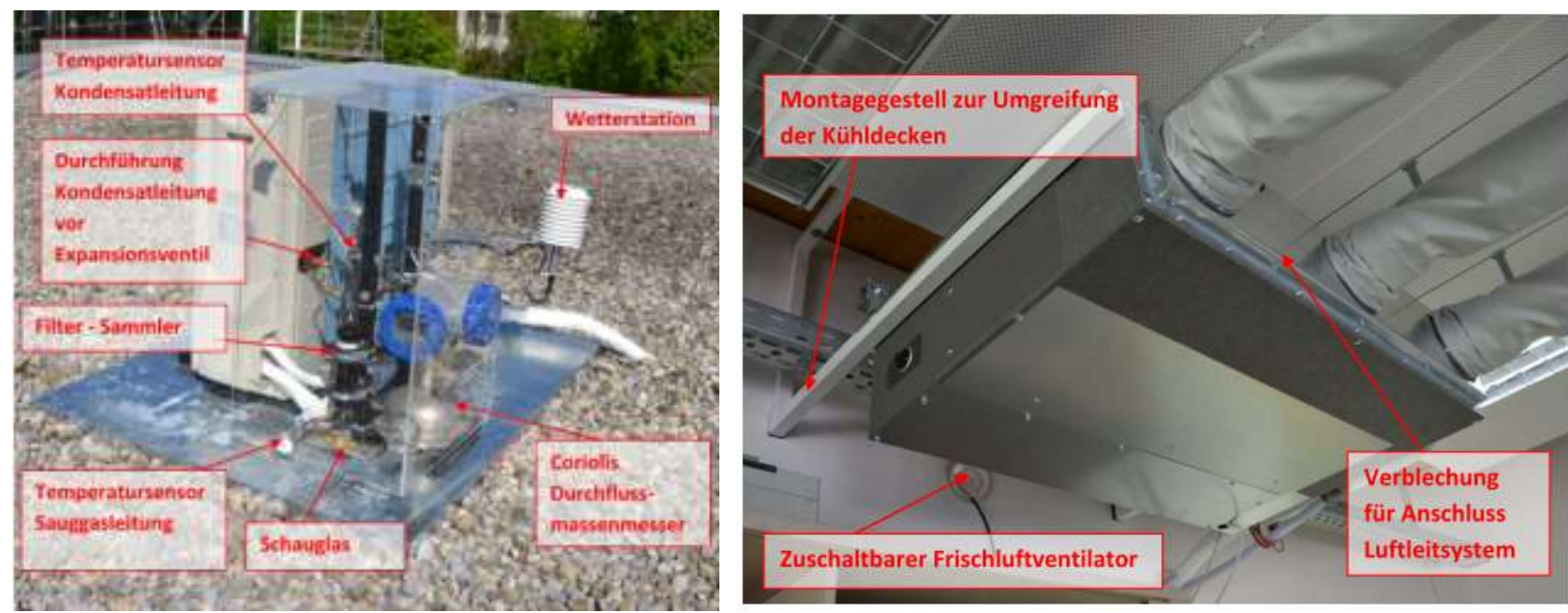

Figure 11: Installation of brand supplier Mono-split-unit at ZAE Bayern [EvaSolK 2013]

Figure 12 summarizes the measurement results of the field test. It includes operation hours, mean EER and cooling capacity versus outdoor temperature for both Mono-split units. Operation hours distribution of both field test is over a wide range similar. The number of operation hours below $14^{\circ} \mathrm{C}$ and above $32^{\circ} \mathrm{C}$ are very limited, resulting in a lower validity for mean EER and mean cooling capacity in that temperature range.

The EER of the brand supplier unit increases from about 3.0 at $35^{\circ} \mathrm{C}$ up to 6.1 at $17^{\circ} \mathrm{C}$ outdoor temperature. Accumulated cooling generation and energy consumption result in a SEER of 4.68 . EER of the budget unit increases from 3.0 at $35^{\circ} \mathrm{C}$ up to 4.2 at $15^{\circ} \mathrm{C}$ outdoor temperature. Accumulated cooling generation and energy consumption results in a SEER of 3.47 . The brand supplier unit shows an overall higher EER compared to the budget unit. The difference is negligible for high outdoor temperatures but increases with decreasing outdoor temperatures. At lower temperatures advantages from variable speed technology become effective. While mean cooling capacity for budget unit is more or less constant over the full outdoor temperature range it decreases for the brand supplier unit from about $4.0 \mathrm{~kW}$ at $34{ }^{\circ} \mathrm{C}$ down to $2.0 \mathrm{~kW}$ at $14{ }^{\circ} \mathrm{C}$ outdoor temperature.

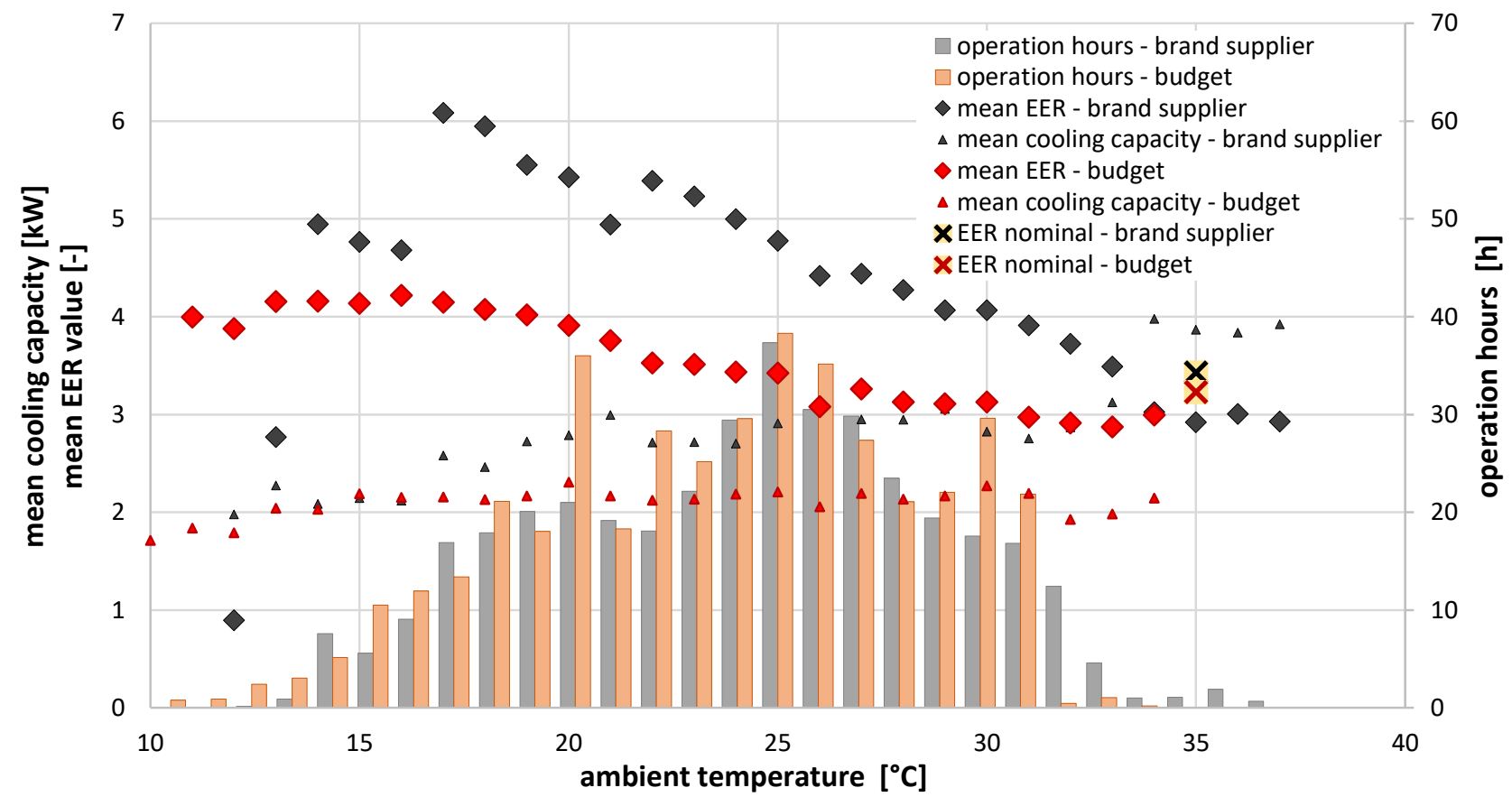

Figure 12: Comparision of EER, mean cooling capacitity and corresponding distribiution of operation hours versus outdoor temperature for Mono-split units in field test 


\section{Details of budget unit field test}

Data of field test is divided into three-time series (cooling period 2011, cooling period 2012 until August, cooling period 2012 August ongoing). Different EER levels can be observed (Figure 13, differently filled circles). Efficiency decreases from 2011 to 2012 due to a refrigerant leakage at a sensor installed in the refrigerant cycle. Efficiency increased significantly after maintenance: calculated EER values between 3.1 and 4.8 were obtained during the last cooling period. Claimed efficiency data of the manufacturer were achieved. During first operation cycle per day EER values are significantly lower (Figure 13, cross makers vs. circle markers). The experimental results show significantly higher EERs compared to characteristic calculation based on DIN V 18599.

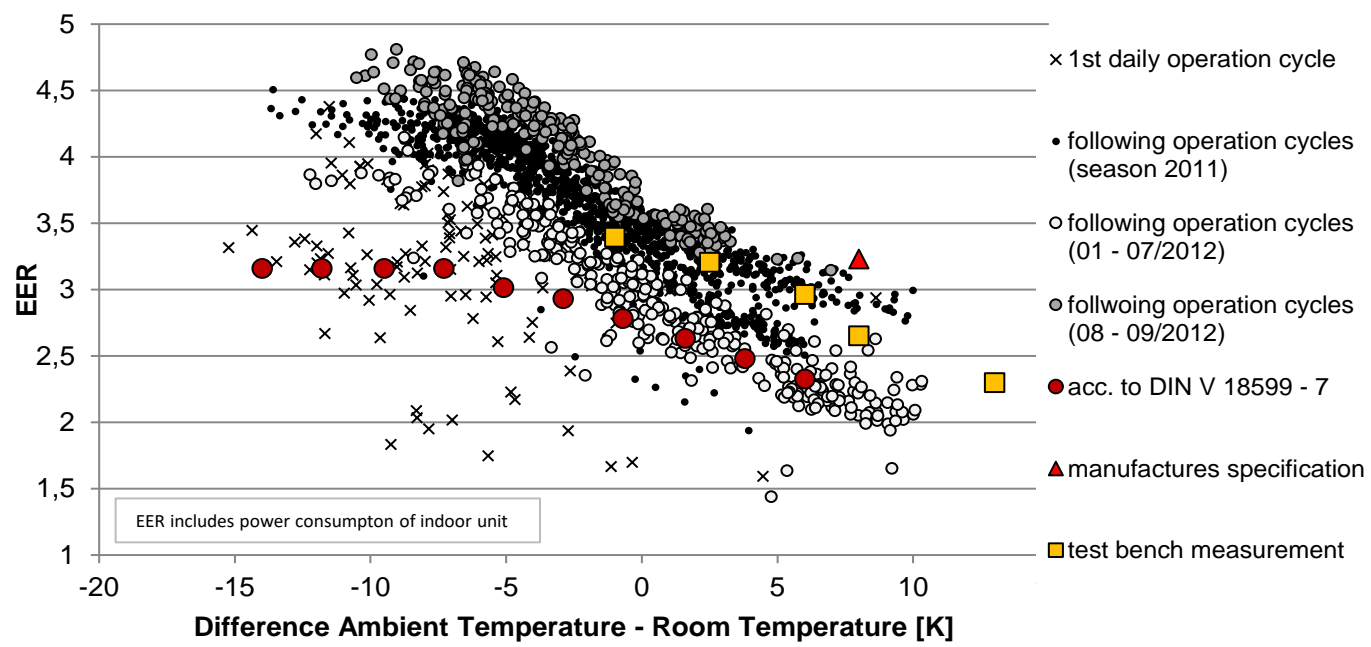

Figure 13: Resulting EER values of budget unit in field test and corresponding EER characteristics acc. to DIN V 18599-7 [EvaSolk 2013]

\section{Details of brand supplier unit field test}

Figure 14 shows resulting EER values of the brand supplier Mono-split unit and part load distribution versus cooling capacity range. More than $40 \%$ of the total cooling generation is done at a cooling capacity range between 2.0 and $2.5 \mathrm{~kW}$, corresponding to a part load factor between 40 and $50 \%$. The remaining cooling generation is mainly distributed over the capacity range 2.5 to $4.5 \mathrm{~kW}$. Average EER shows increasing value from about 3.8 at maximum cooling capacity up to 6.0 at 2.5 to $3.0 \mathrm{~kW}$ cooling capacity. With further decreasing cooling capacity the average EER decreases down to 3.75 at 1.0 to 1.5 kW cooling capacity. For cooling capacities below $1.0 \mathrm{~kW}$ the EER decrease dramatically down to 1.5.

Measured EER and EER based on DIN 18599-7 (red filled circles) shows similar characteristic but with steeper slops for the measured values. 


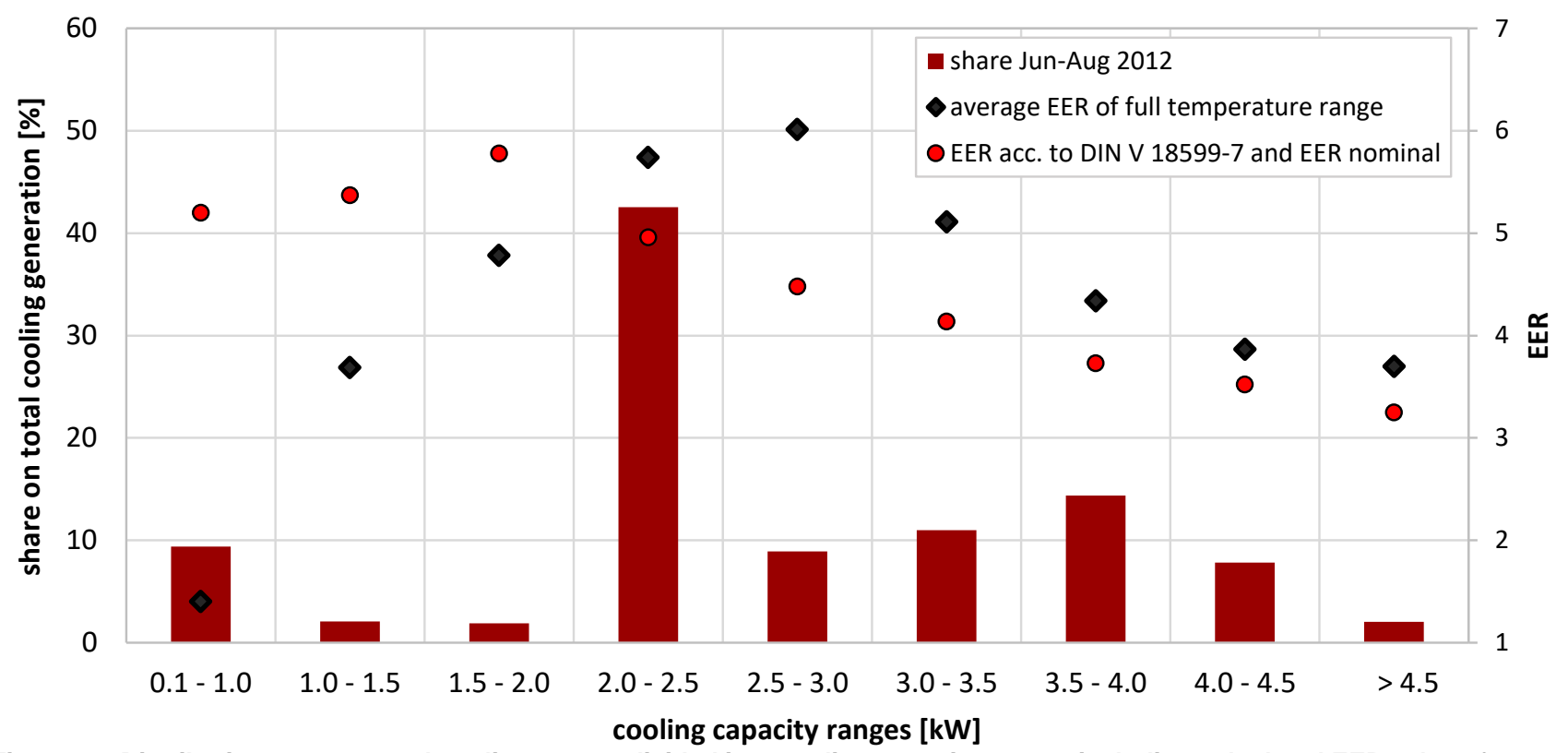

Figure 14: Distribution on generated cooling energy divided into cooling capacity ranges including calculated EER values for Mono-split unit from band supplier for cooling period June to August 2012 [Evasolk 2013]

\subsection{VRF}

A VRF-system containing of six outdoor units with a rated cooling capacity of $40 \mathrm{~kW}$ was installed in spring of 2011 at ILK Dresden for cooling of the office building. The measured outdoor unit supplies cooling for 25 indoor units in offices orientated to south and north.

Figure 15 shows the EER characteristic depending on ambient temperature for different cooling capacity ranges. Energy consumption of the indoor units is not considered. For cooling capacities larger than $10 \mathrm{~kW}(25 \%$ of rated cooling capacity) the EER increases significantly with decreasing ambient temperature from about 3.8 at $32^{\circ} \mathrm{C}$ ambient temperature to about 10 at $15^{\circ} \mathrm{C}$ ambient temperature. For lower cooling capacities the EER level decreases down to a range of 2 to 3 . The increase with decreasing ambient temperature is less significant. Compared to the characteristic according to DIN V 18599-7, the EER increase for decreasing ambient temperature is similar down to about $20^{\circ} \mathrm{C}$. For lower ambient temperatures the calculated characteristic acc. to DIN V18599-7 shows a significant decreasing, which was not the case for measured VRF system.

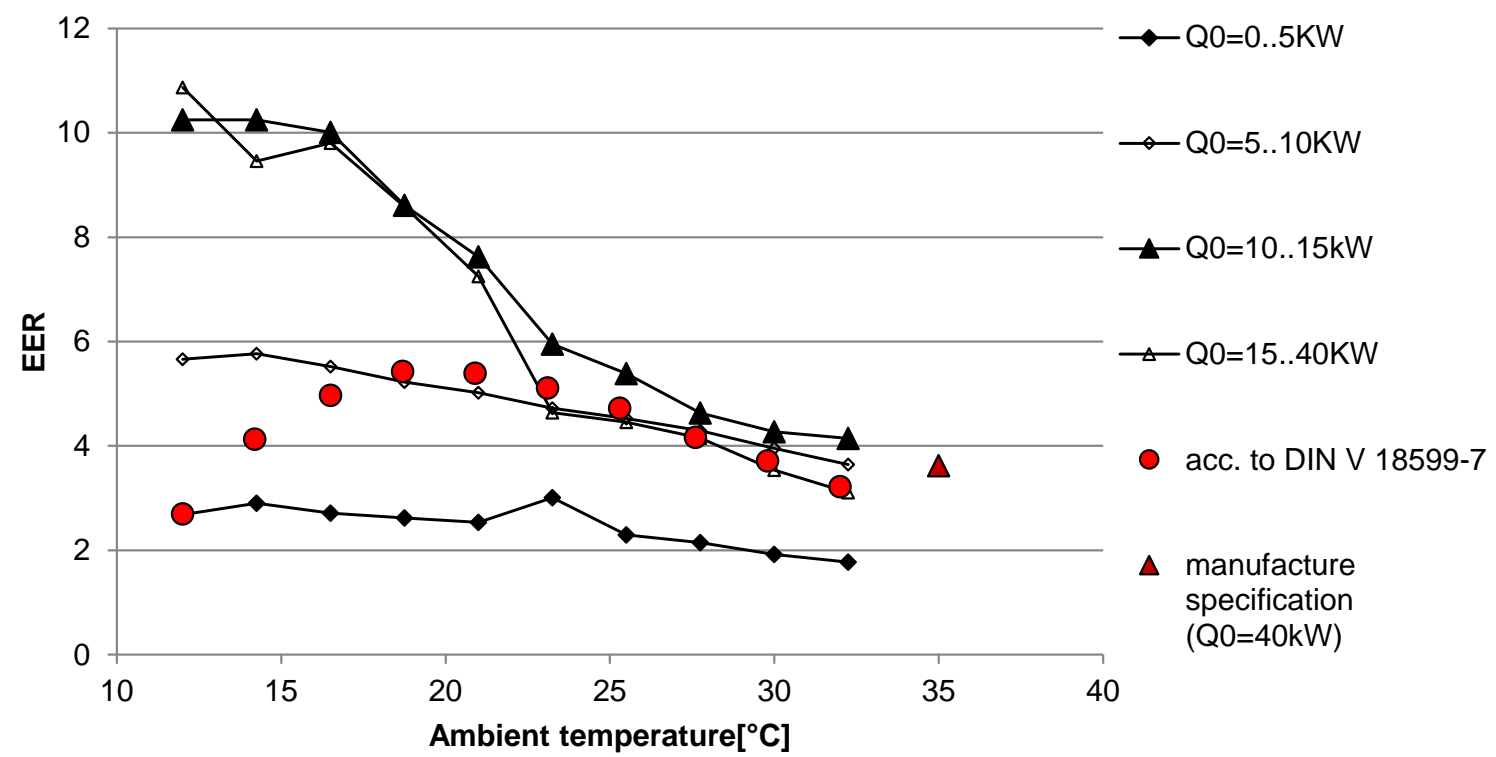

Figure 15: Measured and calculated EER characteristic depending on cooling capacity and ambient temperature for VRF system in field test 
Based on the significant part load influence shown in Figure 15, the measurement data has been analyzed for different cooling capacity ranges. The distribution of the cooling capacity ranges with respect to the total generated cooling energy is shown in Figure 16 for the cooling periods July to November 2011 and March to September 2012. During cooling period 2011 about 46 $\%$ of the total cooling energy was generated at a cooling capacity lower than $5 \mathrm{~kW}$, corresponding to a part load factor below $12.5 \%$ ), with an average EER of 2.5. At 10 to $15 \mathrm{~kW}$ the maximum average EER of 5.2 was achieved.

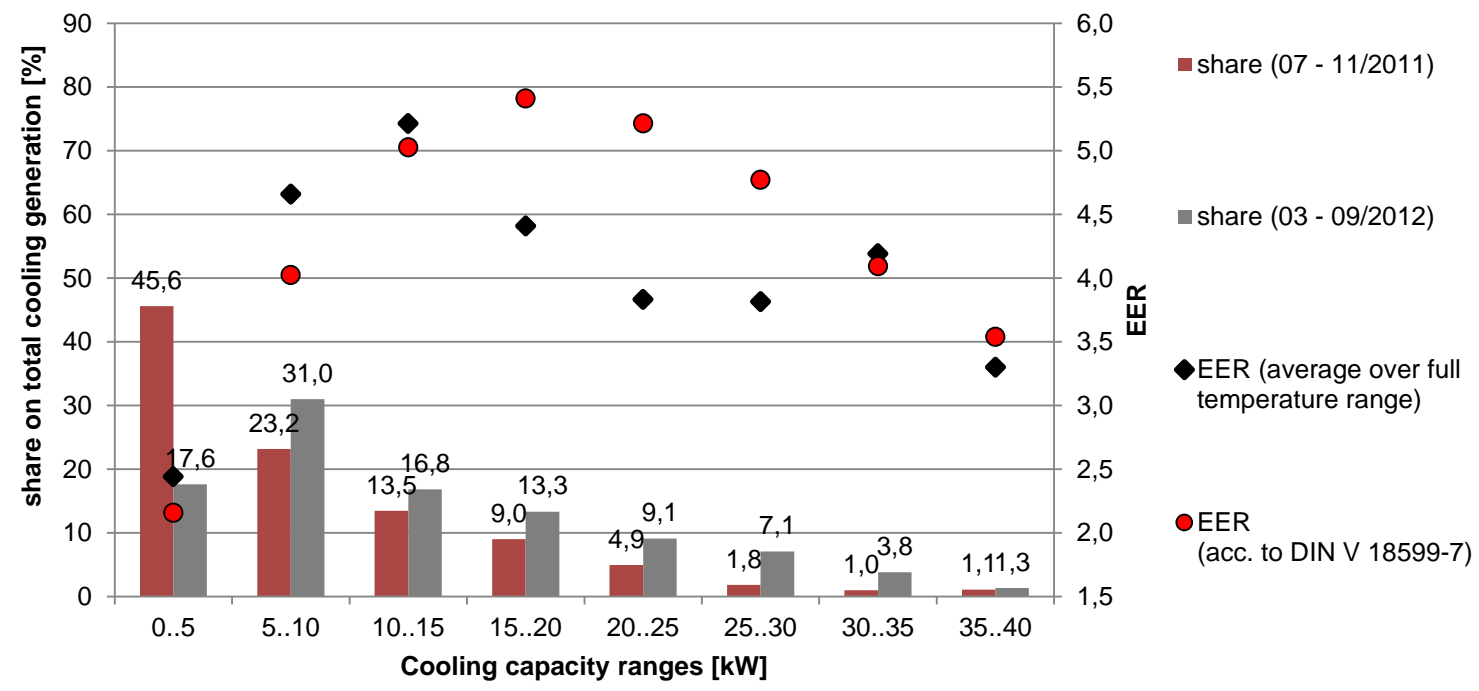

Figure 16: Distribution on generated cooling energy divided into cooling capacity ranges including calculated EER values for two cooling periods

EER characteristic is very similar compared to DIN V 18599-7 EER characteristic, with deviations to lower values in a part load range from 40 to $75 \%$. Down to a part load factor of $40 \%$ advantages of variable speed technology leading to an increasing efficiency. Below part load factors of $25 \%$, several decreasing efficiency effects exceeding the increasing efficiency effect of the part load operation:

fixed condensing temperature limit: a minimum condensing temperature is set in the outdoor unit to avoid evaporation in the liquid distribution pipe and to ensure proper function and control of indoor units $\rightarrow$ the compressor works at a higher-pressure ratio than thermodynamically required for the desired cooling capacity

oil management requires adequate velocities in evaporator and suctions pipes, to ensure a correct oil level in the compressor, oil return operation cycles with full valve openings and high compressor frequency are included during normal operation resulting in an additional energy consumption

The comfort and functionality of VRF-units leads in the specific unit investigated in the field test to inefficient operation in low part load ranges. 


\section{Bibliography}

[AHRI 340/360] AHRI Standard 340/360: Performance Rating of Commercial and Industrial Unitary Air-conditioning and Heat Pump Equipment, AHRI, 2015

[EN 14825] DIN EN 14825: Luftkonditionierer, Flüssigkeitskühlsätze und Wärmepumpen mit elektrisch angetriebenen Verdichtern zur Raumbeheizung und -kühlung - Prüfung und Leistungsbemessung unter Teillastbedingungen und Berechnung der saisonalen Arbeitszahl, Normaussschuss Kältetechnik (FNKä), 2013

[EvaSolk 2013] Wiemken, E. and Safarik, M. et al.: EvaSolK - Evaluierung der Chancen und Grenzen von solarer Kühlung im Vergleich zu Referenztechnologien - Schlussbericht, 2013

[Inspire] iNSPiRe Project www.inspirefp7.eu The research leading to the results exposed has received funding from the European Commission's 7th Framework Programme 2007-2013 under GA n 314461.

[ISO 16538] International Standard ISO 16538-1:2013: Air-cooled air conditioners and air-to-air heat pumps - Testing and calculation methods for seasonal performance factors. Part 1: cooling seasonal performance factor, ISO, 2013

[MALENKOVIC] Malenkovic I, Eicher S., Bony J. Definition of main system boundaries and performance figures for reporting on SHP systems- A technical report of Subtask B - Deliverable B1.1. IEA SHC Task 44, HPP Annex 38, 2012

[SBZ 2015] Sanitär.Heizung.Klima: Durchblick bei COP, SCOP and ESCOP, Issue 18, page 44 - 46, 2018

[SEAD AC] SEAD Super-Efficient Equipment and Appliances Deployment: SEAD Air Conditioner Webinar, Clean Energy Ministerial.org, 26th November 2013 


\section{Appendix}

\subsection{Coefficient of performances}

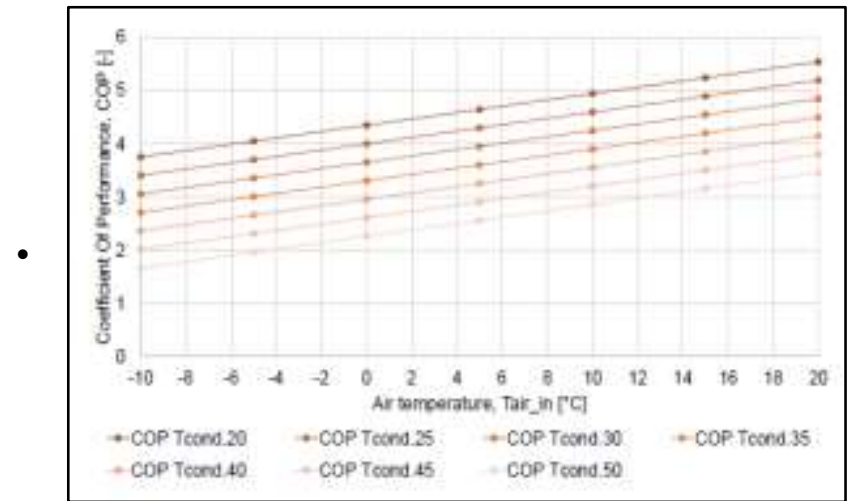

Figure 17 - Coefficient Of Performance for Air to Water Heat Pump in heating mode as a function of the ambient air and the inlet water temperature at the condensing side

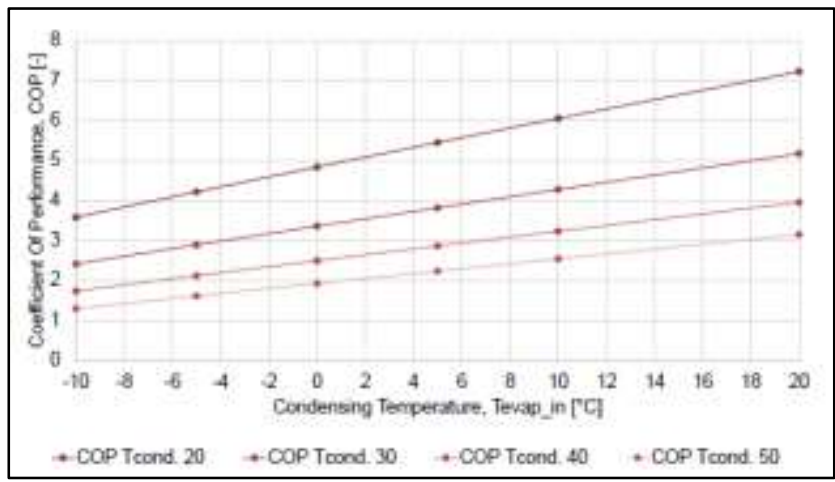

Figure 19 - Coefficient of Performance for Water to Water Heat Pump in winter mode as a function of the ambient air and the inlet water temperature at condensing side.

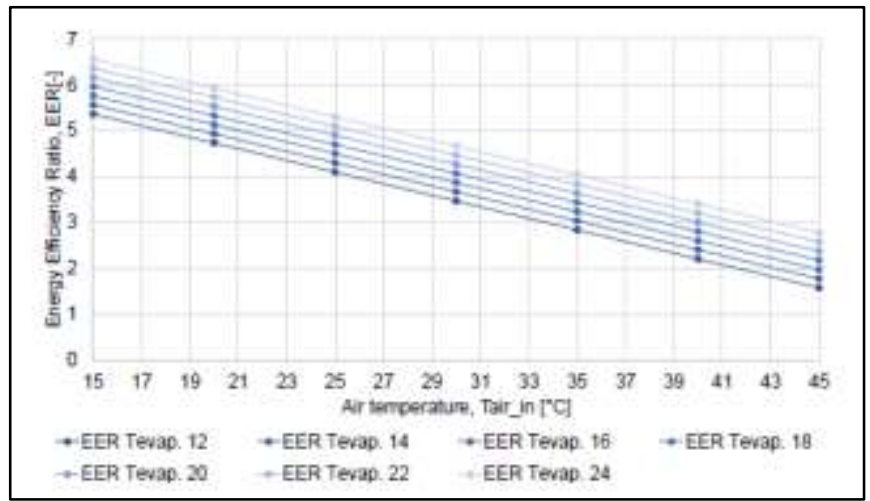

Figure 18 - Energy Efficiency Ratio for the Air to Water Heat Pump in cooling mode as a function of the ambient air and the inlet water temperature at evaporator side

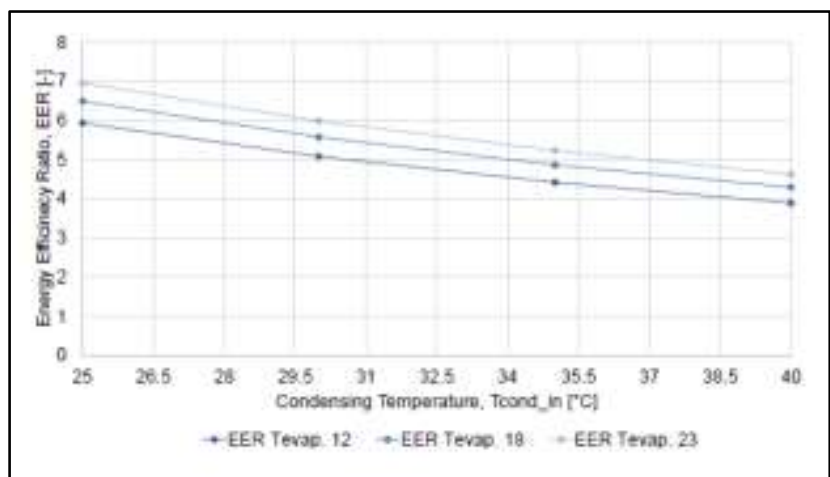

Figure 20 - Energy Efficiency Ratio for the Water to Water Heat Pump in cooling mode as a function of the ambient air and the inlet water temperature at evaporator side 


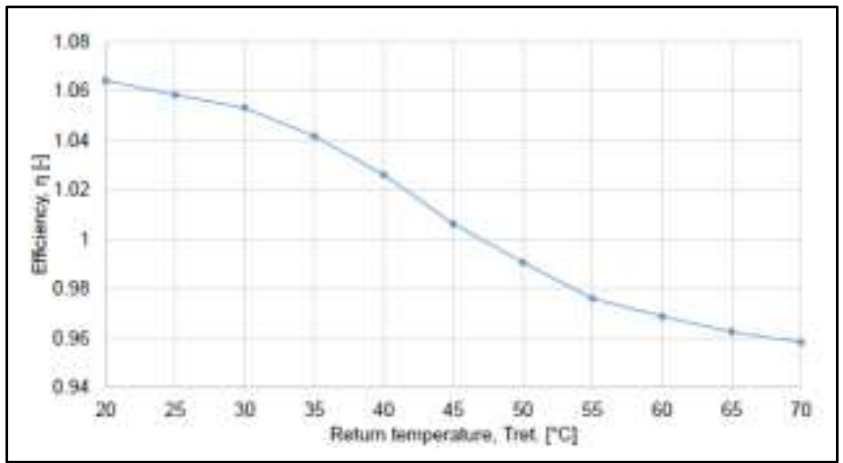

Figure 21 - Efficiency of the condensing boiler as a function of the return temperature of the water. 


\subsection{Results of the parametric study}

Table 9: Energy results for location Rome

\begin{tabular}{|c|c|c|c|c|c|c|c|c|c|}
\hline \multicolumn{3}{|c|}{$\begin{array}{c}\text { climate mediterranean } \\
\text { e.g. Rome }\end{array}$} & $\begin{array}{l}\text { SPF_DHW } \\
\text { (only HP) }\end{array}$ & $\begin{array}{l}\text { SPF_HEAT } \\
\text { (only HP) }\end{array}$ & $\begin{array}{l}\text { SPF_COOL } \\
\text { (only HP) }\end{array}$ & $\begin{array}{c}\mathrm{PE} \\
\text { primary } \\
\text { energy } \\
\text { consumption }\end{array}$ & $\begin{array}{c}\text { PER } \\
\text { primary } \\
\text { energy } \\
\text { ratio }\end{array}$ & $\begin{array}{c}\text { FET final } \\
\text { thermal } \\
\text { energy } \\
\text { consumption }\end{array}$ & $\begin{array}{c}\text { FEE } \\
\text { final } \\
\text { energy } \\
\text { consumption }\end{array}$ \\
\hline & & & {$[-]$} & {$[-]$} & {$[-]$} & $\mathrm{kWh} / \mathrm{m}^{2} \mathrm{y}$ & {$[-]$} & $\mathrm{kWh} / \mathrm{m}^{2} \mathrm{y}$ & $\mathrm{kWh} / \mathrm{m}^{2} \mathrm{y}$ \\
\hline \multirow[t]{6}{*}{ SFH 15} & AWHP & radiant ceiling & 2,1 & 3,1 & 3,7 & 82,9 & 0,9 & 0,0 & 28,8 \\
\hline & & fan coils & 2,1 & 2,2 & 2,9 & 94,3 & 0,7 & 0,0 & 32,8 \\
\hline & GWHP & radiant ceiling & 1,9 & 3,3 & 4,3 & 80,2 & 0,9 & 0,0 & 27,9 \\
\hline & & fan coils & 2,0 & 2,3 & 3,3 & 92,9 & 0,8 & 0,0 & 32,3 \\
\hline & gas boiler & radiant ceiling & 19,8 & 25,7 & 5,3 & 104,3 & 0,7 & 59,5 & 11,6 \\
\hline & & fan coils & 16,3 & 20,2 & 5,3 & 100,4 & 0,7 & 55,6 & 11,9 \\
\hline \multirow[t]{6}{*}{ SFH 25} & AWHP & radiant ceiling & 2,1 & 3,3 & 3,6 & 92,9 & 0,9 & 0,0 & 32,3 \\
\hline & & fan coils & 2,1 & 2,4 & 2,9 & 103,0 & 0,8 & 0,0 & 35,8 \\
\hline & GWHP & radiant ceiling & 1,9 & 3,3 & 4,2 & 90,2 & 0,9 & 0,0 & 31,4 \\
\hline & & fan coils & 1,9 & 2,4 & 3,3 & 102,4 & 0,8 & 0,0 & 35,6 \\
\hline & gas boiler & radiant ceiling & 20,5 & 33,8 & 5,2 & 122,0 & 0,6 & 74,4 & 11,6 \\
\hline & & fan coils & 16,9 & 26,3 & 5,2 & 113,6 & 0,7 & 66,8 & 11,8 \\
\hline \multirow[t]{6}{*}{ SFH 45} & AWHP & radiant ceiling & 2,1 & 3,4 & 3,4 & 96,3 & 1,1 & 0,0 & 33,5 \\
\hline & & fan coils & 2,1 & 2,6 & 2,8 & 102,8 & 0,9 & 0,0 & 35,7 \\
\hline & GWHP & radiant ceiling & 1,9 & 3,3 & 4,2 & 96,8 & 1,0 & 0,0 & 33,6 \\
\hline & & fan coils & 1,9 & 2,4 & 3,4 & 104,3 & 0,9 & 0,0 & 36,2 \\
\hline & gas boiler & radiant ceiling & 21,2 & 46,4 & 5,2 & 145,5 & 0,7 & 106,8 & 6,3 \\
\hline & & fan coils & 17,5 & 34,8 & 5,2 & 124,6 & 0,7 & 88,7 & 6,6 \\
\hline \multirow[t]{6}{*}{ SFH 70} & AWHP & radiant ceiling & 2,1 & 3,4 & 3,3 & 118,8 & 1,1 & 0,0 & 41,3 \\
\hline & & fan coils & 2,1 & 2,6 & 2,8 & 121,8 & 0,9 & 0,0 & 42,3 \\
\hline & GWHP & radiant ceiling & 1,8 & 3,1 & 3,9 & 124,2 & 1,0 & 0,0 & 43,2 \\
\hline & & fan coils & 1,9 & 2,5 & 3,3 & 126,0 & 0,9 & 0,0 & 43,8 \\
\hline & gas boiler & radiant ceiling & 21,7 & 51,6 & 5,2 & 183,8 & 0,7 & 137,4 & 6,9 \\
\hline & & fan coils & 17,9 & 39,7 & 5,2 & 148,5 & 0,7 & 107,3 & 7,2 \\
\hline \multirow[t]{6}{*}{ sMFH 15} & AWHP & radiant ceiling & 2,5 & 3,2 & 3,8 & 77,1 & 1,0 & 0,0 & 26,8 \\
\hline & & fan coils & 2,5 & 2,2 & 1,8 & 94,6 & 0,6 & 0,0 & 32,9 \\
\hline & GWHP & radiant ceiling & 2,5 & 3,5 & 3,9 & 75,7 & 1,0 & 0,0 & 26,3 \\
\hline & & fan coils & 2,5 & 2,3 & 2,0 & 92,4 & 0,7 & 0,0 & 32,1 \\
\hline & gas boiler & radiant ceiling & 72,6 & 56,6 & 5,1 & 90,4 & 0,8 & 47,8 & 11,6 \\
\hline & & fan coils & 71,6 & 23,7 & 5,3 & 88,1 & 0,8 & 45,6 & 11,7 \\
\hline \multirow[t]{6}{*}{ sMFH 25} & AWHP & radiant ceiling & 2,5 & 3,3 & 3,8 & 82,5 & 1,0 & 0,0 & 28,7 \\
\hline & & fan coils & 2,5 & 2,2 & 1,8 & 102,3 & 0,6 & 0,0 & 35,5 \\
\hline & GWHP & radiant ceiling & 2,4 & 3,6 & 3,9 & 80,7 & 1,0 & 0,0 & 28,0 \\
\hline & & fan coils & 2,5 & 2,4 & 2,0 & 99,5 & 0,7 & 0,0 & 34,6 \\
\hline & gas boiler & radiant ceiling & 70,5 & 60,6 & 5,1 & 98,5 & 0,8 & 54,7 & 11,5 \\
\hline & & fan coils & 69,4 & 27,7 & 5,3 & 94,3 & 0,8 & 51,1 & 11,6 \\
\hline \multirow[t]{6}{*}{ sMFH 45} & AWHP & radiant ceiling & 2,6 & 3,6 & 3,7 & 100,0 & 1,2 & 0,0 & 34,7 \\
\hline & & fan coils & 2,6 & 2,4 & 1,8 & 126,0 & 0,8 & 0,0 & 43,8 \\
\hline & GWHP & radiant ceiling & 2,3 & 3,5 & 4,3 & 100,0 & 1,2 & 0,0 & 34,7 \\
\hline & & fan coils & 2,3 & 2,4 & 2,3 & 123,5 & 0,8 & 0,0 & 42,9 \\
\hline & gas boiler & radiant ceiling & 71,1 & 71,8 & 5,0 & 140,5 & 0,8 & 97,4 & 8,5 \\
\hline & & fan coils & 69,9 & 49,9 & 5,2 & 124,3 & 0,8 & 84,2 & 8,3 \\
\hline \multirow[t]{6}{*}{ sMFH 70} & AWHP & radiant ceiling & 2,6 & 3,6 & 3,7 & 108,3 & 1,2 & 0,0 & 37,6 \\
\hline & & fan coils & 2,6 & 2,4 & 1,9 & 132,7 & 0,8 & 0,0 & 46,1 \\
\hline & GWHP & radiant ceiling & 2,3 & 3,5 & 4,4 & 107,3 & 1,2 & 0,0 & 37,3 \\
\hline & & fan coils & 2,4 & 2,4 & 2,4 & 127,4 & 0,8 & 0,0 & 44,3 \\
\hline & gas boiler & radiant ceiling & 70,5 & 71,9 & 5,0 & 153,5 & 0,8 & 107,5 & 8,8 \\
\hline & & fan coils & 69,4 & 50,8 & 5,2 & 131,1 & 0,9 & 89,1 & 8,6 \\
\hline \multirow{4}{*}{$\begin{array}{l}\text { OFF2 } \\
5 \mathrm{fl} / \text { period I } \\
25 \mathrm{kWh} / \mathrm{m}^{2} \mathrm{y}\end{array}$} & AWHP & radiant ceiling & $\mathrm{x}$ & 3,2 & 3,3 & 78,0 & 0,7 & 5,4 & 21,7 \\
\hline & & fan coils & $\mathrm{x}$ & 2,3 & 2,4 & 82,1 & 0,5 & 5,2 & 23,3 \\
\hline & gas boiler & radiant ceiling & $\mathrm{x}$ & 77,7 & 5,2 & 55,9 & 0,9 & 20,0 & 11,1 \\
\hline & & fan coils & $\mathrm{x}$ & 12,4 & 5,0 & 53,7 & 0,8 & 15,9 & 12,1 \\
\hline \multirow{4}{*}{$\begin{array}{l}\text { OFF2 } \\
5 \mathrm{fl} / \text { period I } \\
45 \mathrm{kWh} / \mathrm{m}^{2} \mathrm{y}\end{array}$} & AWHP & radiant ceiling & $\mathrm{x}$ & 3,4 & 3,3 & 94,4 & 0,7 & 8,1 & 24,7 \\
\hline & & fan coils & $\mathrm{x}$ & 2,4 & 2,4 & 97,7 & 0,5 & 7,8 & 26,2 \\
\hline & gas boiler & radiant ceiling & $\mathrm{x}$ & 76,0 & 5,2 & 70,3 & 0,8 & 31,8 & 11,3 \\
\hline & & fan coils & $\mathrm{x}$ & 12,2 & 5,0 & 66,2 & 0,8 & 24,9 & 12,7 \\
\hline
\end{tabular}


Table 10: Energy results for location Stuttgart

\begin{tabular}{|c|c|c|c|c|c|c|c|c|c|}
\hline \multicolumn{3}{|c|}{$\begin{array}{l}\text { climate continental } \\
\text { e.g. Stuttgart }\end{array}$} & \multirow{2}{*}{$\begin{array}{c}\begin{array}{r}\text { SPF_DHW } \\
\text { (only HP) }\end{array} \\
{[-]}\end{array}$} & \multirow{2}{*}{$\begin{array}{c}\begin{array}{c}\text { SPF_HEAT } \\
\text { (only HP) }\end{array} \\
{[-]}\end{array}$} & \multirow{2}{*}{$\begin{array}{c}\text { SPF_COOL } \\
\text { (only HP) }\end{array}$} & \multirow{2}{*}{$\begin{array}{c}\mathrm{PE} \\
\text { primary } \\
\text { energy } \\
\text { consumption } \\
\mathrm{kWh} / \mathrm{m}^{2} \mathrm{y}\end{array}$} & \multirow{2}{*}{$\begin{array}{c}\text { PER } \\
\text { primary } \\
\text { energy } \\
\text { ratio } \\
{[-]}\end{array}$} & \multirow{2}{*}{$\begin{array}{c}\begin{array}{c}\text { FET final } \\
\text { thermal } \\
\text { energy }\end{array} \\
\text { consumption } \\
\mathrm{kWh} / \mathrm{m}^{2} \mathrm{y} \\
\end{array}$} & \multirow{2}{*}{$\begin{array}{c}\text { FEE } \\
\text { final } \\
\text { energy } \\
\text { consumption } \\
\mathrm{kWh} / \mathrm{m}^{2} \mathrm{y} \\
\end{array}$} \\
\hline & - & - & & & & & & & \\
\hline \multirow[t]{6}{*}{ SFH 15} & AWHP & radiant ceiling & 1,9 & 2,9 & 3,4 & 81,6 & 0,7 & 0,0 & 28,3 \\
\hline & & fan coils & 1,9 & 2,0 & 2,5 & 91,2 & 0,6 & 0,0 & 31,7 \\
\hline & GWHP & radiant ceiling & 1,9 & 3,3 & 3,8 & 77,4 & 0,7 & 0,0 & 26,9 \\
\hline & & fan coils & 1,9 & 2,3 & 3,1 & 87,3 & 0,6 & 0,0 & 30,3 \\
\hline & gas boiler & radiant ceiling & 20,5 & 29,8 & 5,5 & 111,0 & 0,5 & 73,2 & 8,3 \\
\hline & & fan coils & 16,8 & 24,3 & 5,5 & 106,1 & 0,5 & 68,4 & 8,6 \\
\hline \multirow[t]{6}{*}{ SFH 25} & AWHP & radiant ceiling & 1,9 & 3,0 & 3,3 & 87,5 & 0,7 & 0,0 & 30,4 \\
\hline & & fan coils & 1,9 & 2,1 & 2,5 & 99,1 & 0,6 & 0,0 & 34,4 \\
\hline & GWHP & radiant ceiling & 1,8 & 3,3 & 3,9 & 83,4 & 0,8 & 0,0 & 29,0 \\
\hline & & fan coils & 1,9 & 2,3 & 3,0 & 94,9 & 0,7 & 0,0 & 33,0 \\
\hline & gas boiler & radiant ceiling & 20,9 & 33,4 & 5,4 & 122,3 & 0,5 & 82,8 & 8,2 \\
\hline & & fan coils & 17,2 & 27,2 & 5,5 & 116,4 & 0,5 & 77,1 & 8,5 \\
\hline \multirow[t]{6}{*}{ SFH 45} & AWHP & radiant ceiling & 1,9 & 3,1 & 3,3 & 94,2 & 0,9 & 0,0 & 32,7 \\
\hline & & fan coils & 1,9 & 2,3 & 2,6 & 107,6 & 0,8 & 0,0 & 37,4 \\
\hline & GWHP & radiant ceiling & 1,8 & 3,3 & 3,9 & 91,2 & 1,0 & 0,0 & 31,7 \\
\hline & & fan coils & 1,8 & 2,4 & 3,1 & 105,2 & 0,8 & 0,0 & 36,5 \\
\hline & gas boiler & radiant ceiling & 21,6 & 42,7 & 5,4 & 144,4 & 0,6 & 111,6 & 4,0 \\
\hline & & fan coils & 17,9 & 35,1 & 5,5 & 132,1 & 0,6 & 100,4 & 4,3 \\
\hline \multirow[t]{6}{*}{ SFH 70} & AWHP & radiant ceiling & 1,9 & 3,1 & 3,3 & 106,8 & 0,9 & 0,0 & 37,1 \\
\hline & & fan coils & 1,9 & 2,3 & 2,6 & 119,7 & 0,8 & 0,0 & 41,6 \\
\hline & GWHP & radiant ceiling & 1,8 & 3,2 & 3,9 & 104,8 & 1,0 & 0,0 & 36,4 \\
\hline & & fan coils & 1,8 & 2,4 & 3,1 & 118,1 & 0,8 & 0,0 & 41,1 \\
\hline & gas boiler & radiant ceiling & 22,0 & 46,0 & 5,4 & 165,9 & 0,6 & 129,1 & 4,2 \\
\hline & & fan coils & 18,3 & 37,8 & 5,5 & 147,0 & 0,6 & 112,5 & 4,5 \\
\hline \multirow[t]{6}{*}{ sMFH 15} & AWHP & radiant ceiling & 2,3 & 3,0 & 3,9 & 67,3 & 0,8 & 0,0 & 23,4 \\
\hline & & fan coils & 2,3 & 2,0 & 2,2 & 76,8 & 0,6 & 0,0 & 26,7 \\
\hline & GWHP & radiant ceiling & 2,4 & 3,4 & 4,5 & 62,3 & 0,9 & 0,0 & 21,7 \\
\hline & & fan coils & 2,4 & 2,3 & 2,6 & 71,5 & 0,7 & 0,0 & 24,8 \\
\hline & gas boiler & radiant ceiling & 62,9 & 54,8 & 5,3 & 81,2 & 0,7 & 49,3 & 7,8 \\
\hline & & fan coils & 62,0 & 23,5 & 5,5 & 80,2 & 0,7 & 47,8 & 8,1 \\
\hline \multirow[t]{6}{*}{ sMFH 25} & AWHP & radiant ceiling & 2,3 & 3,0 & 3,7 & 77,6 & 0,8 & 0,0 & 27,0 \\
\hline & & fan coils & 2,3 & 2,1 & 2,1 & 91,2 & 0,7 & 0,0 & 31,7 \\
\hline & GWHP & radiant ceiling & 2,3 & 3,4 & 4,4 & 72,1 & 0,9 & 0,0 & 25,0 \\
\hline & & fan coils & 2,3 & 2,3 & 2,5 & 84,3 & 0,7 & 0,0 & 29,3 \\
\hline & gas boiler & radiant ceiling & 60,5 & 62,5 & 5,3 & 99,1 & 0,6 & 65,4 & 7,4 \\
\hline & & fan coils & 59,7 & 32,3 & 5,4 & 95,0 & 0,7 & 61,2 & 7,7 \\
\hline \multirow[t]{6}{*}{ sMFH 45} & AWHP & radiant ceiling & 2,3 & 3,2 & 3,8 & 83,4 & 1,0 & 0,0 & 29,0 \\
\hline & & fan coils & 2,3 & 2,2 & 2,2 & 103,3 & 0,8 & 0,0 & 35,9 \\
\hline & GWHP & radiant ceiling & 2,2 & 3,4 & 4,5 & 80,2 & 1,1 & 0,0 & 27,9 \\
\hline & & fan coils & 2,2 & 2,3 & 2,6 & 98,5 & 0,8 & 0,0 & 34,2 \\
\hline & gas boiler & radiant ceiling & 61,1 & 68,9 & 5,2 & 117,8 & 0,7 & 89,5 & 3,9 \\
\hline & & fan coils & 60,1 & 44,3 & 5,4 & 109,6 & 0,7 & 82,1 & 4,1 \\
\hline sMFH 70 & AWHP & radiant ceiling & 2,3 & 3,2 & 3,6 & 102,9 & 1,1 & 0,0 & 35,8 \\
\hline & & fan coils & 2,3 & 2,2 & 2,1 & 125,9 & 0,8 & 0,0 & 43,7 \\
\hline & GWHP & radiant ceiling & 2,2 & 3,4 & 4,6 & 99,2 & 1,1 & 0,0 & 34,5 \\
\hline & & fan coils & 2,3 & 2,4 & 2,6 & 119,5 & 0,8 & 0,0 & 41,5 \\
\hline & gas boiler & radiant ceiling & 59,6 & 68,6 & 5,1 & 155,0 & 0,7 & 121,0 & 3,8 \\
\hline & & fan coils & 58,7 & 50,7 & 5,4 & 136,7 & 0,7 & 105,2 & 3,9 \\
\hline OFF2 & AWHP & radiant ceiling & $x$ & 2,8 & 2,9 & 81,2 & 0,5 & 8,6 & 19,6 \\
\hline $5 \mathrm{fl} /$ period I & & fan coils & $x$ & 1,9 & 2,6 & 89,5 & 0,4 & 9,2 & 21,9 \\
\hline $25 \mathrm{kWh} / \mathrm{m}^{2} \mathrm{y}$ & gas boiler & radiant ceiling & $x$ & 71,6 & 5,4 & 57,8 & 0,7 & 29,3 & 7,9 \\
\hline & & fan coils & $x$ & 12,1 & 5,4 & 56,6 & 0,6 & 24,9 & 9,4 \\
\hline OFF2 & AWHP & radiant ceiling & $x$ & 3,0 & 2,7 & 114,7 & 0,5 & 13,9 & 25,9 \\
\hline $5 \mathrm{fl} /$ period I & & fan coils & $x$ & 1,6 & 2,3 & 144,2 & 0,3 & 17,2 & 32,9 \\
\hline $45 \mathrm{kWh} / \mathrm{m}^{2} \mathrm{y}$ & gas boiler & radiant ceiling & $x$ & 78,5 & 5,4 & 84,7 & 0,7 & 51,9 & 7,9 \\
\hline & & fan coils & $\mathrm{x}$ & 12,5 & 5,3 & 83,7 & 0,6 & 44,7 & 10,6 \\
\hline
\end{tabular}


Table 11: Energy results for location Madrid

\begin{tabular}{|c|c|c|c|c|c|c|c|c|c|}
\hline & $\begin{array}{l}\text { limate southe } \\
\text { e.g. Madri }\end{array}$ & dry & SPF_DHW & SPF_HEAT & SPF_COOL & $\begin{array}{c}\text { PE } \\
\text { primary } \\
\text { energy }\end{array}$ & $\begin{array}{c}\text { PER } \\
\text { primary } \\
\text { energy }\end{array}$ & $\begin{array}{l}\text { FET final } \\
\text { thermal } \\
\text { energy }\end{array}$ & $\begin{array}{l}\text { FEE final } \\
\text { electric energy }\end{array}$ \\
\hline & & & {$[-]$} & {$[-]$} & {$[-]$} & $\mathrm{kWh} / \mathrm{m}^{2} \mathrm{y}$ & {$[-]$} & $\mathrm{kWh} / \mathrm{m}^{2} \mathrm{y}$ & $\mathrm{kWh} / \mathrm{m}^{2} \mathrm{y}$ \\
\hline SFH 15 & AWHP & radiant ceiling & 2,0 & 2,9 & 3,6 & 81,8 & 0,8 & 0,0 & 28,4 \\
\hline & & fan coils & 2,0 & 2,0 & 2,8 & 90,0 & 0,7 & 0,0 & 31,3 \\
\hline & GWHP & radiant ceiling & 1,9 & 3,2 & 4,4 & 76,7 & 0,9 & 0,0 & 26,6 \\
\hline & & fan coils & 1,9 & 2,2 & 3,3 & 85,9 & 0,7 & 0,0 & 29,9 \\
\hline & gas boiler & radiant ceiling & 19,5 & 20,8 & 5,0 & 101,3 & 0,7 & 54,6 & 12,6 \\
\hline & & fan coils & 16,1 & 16,4 & 5,0 & 98,1 & 0,7 & 51,3 & 12,8 \\
\hline SFH 25 & AWHP & radiant ceiling & 2,0 & 3,1 & 3,4 & 99,5 & 0,9 & 0,0 & 34,6 \\
\hline & & fan coils & 2,0 & 2,3 & 2,7 & 110,0 & 0,7 & 0,0 & 38,2 \\
\hline & GWHP & radiant ceiling & 1,9 & 3,4 & 4,2 & 93,9 & 0,9 & 0,0 & 32,6 \\
\hline & & fan coils & 1,9 & 2,4 & 3,2 & 105,0 & 0,8 & 0,0 & 36,5 \\
\hline & gas boiler & radiant ceiling & 20,4 & 34,5 & 4,9 & 127,5 & 0,7 & 76,3 & 12,7 \\
\hline & & fan coils & 16,9 & 27,5 & 4,9 & 120,6 & 0,7 & 69,8 & 13,0 \\
\hline SFH 45 & AWHP & radiant ceiling & 2,0 & 3,3 & 3,4 & 108,4 & 1,0 & 0,0 & 37,7 \\
\hline & & fan coils & 2,0 & 2,5 & 2,7 & 119,7 & 0,8 & 0,0 & 41,6 \\
\hline & GWHP & radiant ceiling & 1,9 & 3,3 & 4,2 & 104,0 & 1,1 & 0,0 & 36,1 \\
\hline & & fan coils & 1,9 & 2,4 & 3,2 & 116,1 & 0,9 & 0,0 & 40,3 \\
\hline & gas boiler & radiant ceiling & 21,2 & 45,6 & 4,9 & 152,1 & 0,7 & 106,5 & 8,8 \\
\hline & & fan coils & 17,6 & 35,9 & 4,9 & 137,9 & 0,7 & 93,8 & 9,1 \\
\hline SFH 70 & AWHP & radiant ceiling & 2,1 & 3,4 & 3,1 & 132,3 & 1,0 & 0,0 & 46,0 \\
\hline & & fan coils & 2,0 & 2,6 & 2,6 & 140,3 & 0,8 & 0,0 & 48,8 \\
\hline & GWHP & radiant ceiling & 1,8 & 3,1 & 4,1 & 130,8 & 1,0 & 0,0 & 45,4 \\
\hline & & fan coils & 1,9 & 2,4 & 3,3 & 142,7 & 0,8 & 0,0 & 49,6 \\
\hline & gas boiler & radiant ceiling & 22,1 & 47,4 & 4,8 & 194,6 & 0,7 & 145,6 & 7,3 \\
\hline & & fan coils & 18,3 & 41,5 & 4,8 & 176,3 & 0,7 & 129,6 & 7,6 \\
\hline SMFH 15 & AWHP & radiant ceiling & 2,4 & 3,2 & 3,6 & 82,8 & 1,0 & 0,0 & 28,8 \\
\hline & & fan coils & 2,4 & 2,1 & 2,4 & 95,2 & 0,7 & 0,0 & 33,1 \\
\hline & GWHP & radiant ceiling & 2,4 & 3,6 & 3,9 & 78,7 & 1,0 & 0,0 & 27,3 \\
\hline & & fan coils & 2,5 & 2,4 & 2,6 & 90,3 & 0,8 & 0,0 & 31,4 \\
\hline & gas boiler & radiant ceiling & 73,5 & 59,5 & 4,8 & 95,0 & 0,8 & 50,0 & 12,3 \\
\hline & & fan coils & 72,4 & 26,2 & 5,0 & 92,3 & 0,8 & 47,4 & 12,5 \\
\hline sMFH 25 & AWHP & radiant ceiling & 2,4 & 3,3 & 3,5 & 97,7 & 1,0 & 0,0 & 34,0 \\
\hline & & fan coils & 2,4 & 2,2 & 2,3 & 115,6 & 0,7 & 0,0 & 40,2 \\
\hline & GWHP & radiant ceiling & 2,3 & 3,5 & 4,0 & 93,0 & 1,0 & 0,0 & 32,3 \\
\hline & & fan coils & 2,4 & 2,4 & 2,7 & 108,8 & 0,8 & 0,0 & 37,8 \\
\hline & gas boiler & radiant ceiling & 70,4 & 67,1 & 4,8 & 118,1 & 0,8 & 69,1 & 12,4 \\
\hline & & fan coils & 69,1 & 36,5 & 4,9 & 110,4 & 0,8 & 62,6 & 12,4 \\
\hline sMFH 45 & AWHP & radiant ceiling & 2,5 & 3,4 & 3,5 & 110,0 & 1,1 & 0,0 & 38,2 \\
\hline & & fan coils & 2,5 & 2,4 & 2,3 & 133,8 & 0,8 & 0,0 & 46,5 \\
\hline & GWHP & radiant ceiling & 2,3 & 3,5 & 4,3 & 104,2 & 1,2 & 0,0 & 36,2 \\
\hline & & fan coils & 2,3 & 2,4 & 2,8 & 125,7 & 0,9 & 0,0 & 43,7 \\
\hline & gas boiler & radiant ceiling & 68,4 & 70,0 & 4,7 & 147,7 & 0,8 & 100,9 & 9,5 \\
\hline & & fan coils & 67,4 & 47,7 & 4,9 & 131,5 & 0,8 & 87,7 & 9,4 \\
\hline sMFH 70 & AWHP & radiant ceiling & 2,5 & 3,5 & 3,5 & 127,3 & 1,1 & 0,0 & 44,2 \\
\hline & & fan coils & 2,5 & 2,4 & 2,3 & 152,0 & 0,8 & 0,0 & 52,8 \\
\hline & GWHP & radiant ceiling & 2,3 & 3,5 & 4,4 & 119,7 & 1,2 & 0,0 & 41,6 \\
\hline & & fan coils & 2,4 & 2,5 & 2,9 & 141,5 & 0,9 & 0,0 & 49,1 \\
\hline & gas boiler & radiant ceiling & 72,5 & 74,7 & 4,6 & 178,1 & 0,8 & 125,4 & 9,9 \\
\hline & & fan coils & 71,6 & 56,3 & 4,9 & 152,4 & 0,8 & 104,6 & 9,6 \\
\hline OFF2 & AWHP & radiant ceiling & $\mathrm{x}$ & 3,0 & 2,9 & 100,5 & 0,6 & 8,2 & 26,7 \\
\hline $5 \mathrm{fl} /$ period I & & fan coils & $\mathrm{x}$ & 2,1 & 2,8 & 102,2 & 0,5 & 8,1 & 27,4 \\
\hline $25 \mathrm{kWh} / \mathrm{m}^{2} \mathrm{y}$ & gas boiler & radiant ceiling & $x$ & 70,2 & 4,8 & 69,4 & 0,8 & 30,4 & 11,5 \\
\hline & & fan coils & $\mathrm{x}$ & 12,0 & 4,8 & 65,8 & 0,8 & 24,0 & 12,9 \\
\hline OFF2 & AWHP & radiant ceiling & $\mathrm{x}$ & 3,3 & 2,9 & 133,9 & 0,6 & 13,6 & 32,9 \\
\hline $5 \mathrm{fl} /$ period I & & fan coils & $\mathrm{x}$ & 2,2 & 2,8 & 137,5 & 0,5 & 13,7 & 34,1 \\
\hline $45 \mathrm{kWh} / \mathrm{m}^{2} \mathrm{y}$ & gas boiler & radiant ceiling & $x$ & 81,1 & 4,8 & 98,5 & 0,8 & 54,7 & 11,6 \\
\hline & & fan coils & $x$ & 12,5 & 4,8 & 93,0 & 0,7 & 43,8 & 14,2 \\
\hline
\end{tabular}

Note: the IEA SHC Technology Collaboration Programme (IEA SHC TCP) functions within a framework created by the International Energy Agency (IEA). Views, findings and publications of the IEA SHC TCP do not necessarily represent the views or policies of the IEA Secretariat or of its individual member countries. The IEA SHC TCP and the IEA make no representation or warranty, express or implied, in respect of this paper's content (including its completeness or accuracy) and shall not be responsible for any use of, or reliance on, the paper. 